\title{
Müşterilerin Yiyecek İçecek İşletmeleri Tercihlerinde Etkili Olan Kriterler
}

Dr. Müjdat Ertürk, Girne Öğretmenevi, Girne KKTC, e-posta: mujdate26mail.com

\section{Öz}

Değişen yaşam tarzları ve yaşam koşulları ile karın doyurmanın ötesinde beklentiler yaratan dışarıda yemek yeme olgusu, günümüz ülke ekonomilerinde önemli bir paya sahiptir. Hizmet sektöründe başarının, kaliteli hizmet sunmanın kıstası müşteri beklentilerini en yüksek seviyede karşılamak olduğu göz önünde tutulduğunda, müşteri beklentilerini tespit etmek başarıya ve kaliteli hizmete giden ilk basamaktır. Bu amaçla, bu çalışmada müşterilerin yiyecek içecek işletmeleri tercihlerinde etkili olan kriterler tespit edilmeye ve bu kriterlerin siralaması ile demografik özellikler arasında fark olup olmadığı tespit edilmeye çalışılmıştır. Araştırma anketle veri toplama tekniği ile 705 katılımciya anket uygulamak sureti gerçekleştirilmiştir. Elde edilen veriler frekans, yüzde dağılımı ve sıralama işlemlerine tabi tutulmuştur. Araştırma sonucunda; yemeklerin lezzeti, tuvaletlerin temizliği, personelin ilgisi ve davranışları, yemeklerin kalitesi, yemeklerin tazeliği, ödenen paranın karşılığını vermesi, mutfağın hijyenik olması, uygun fiyatlı olması, personelin kişisel bakımı ve görünüşleri, servis ekipmanlarının hijyenik olması kriterlerinin araştırmaya katılanlar tarafından yiyecek içecek işletmesi seçiminde göz önünde bulundurdukları 10 önemli kriter olduğu ve bu kriterlerin demografik özelliklere göre farklılıklar gösterdiği tespit edilmiştir.

Anahtar Kelimeler: Yiyecek İçecek İşletmeleri, Seçim Kriterleri, Müşteri Beklentileri.

\section{Önerilen Atıf:}

Ertürk, M. (2018). Müşterilerin Yiyecek İçecek İşletmeleri Tercihlerinde Etkili Olan Kriterler, Türk Turizm Araştırmaları Dergisi, Cilt.2, Sayı.1, ss. 85-107. 


\title{
The Criteria that Affect the Consumers' Preferences of Food and Beverage Establishments for Eating Out
}

Dr. Müjdat Ertürk, Kyrenia Teacher House, Kyrenia TRNC, e-mail: mujdate26mail.com

\begin{abstract}
Due to the transformation in life styles and life conditions, eating has gained a meaning that goes beyond its basic semantic area and has got a big share in national economies. Taking into consideration that the path which is going to success in service sector is directly related to fulfill the expectations of the consumers preeminently, to determine the expectations of the consumer is the first step of that success. So, in this study, it is targeted to determine the criteria of the consumers in choosing a food and beverage establishment and to determine the relationship between the order of those criteria and the demographic peculiarities of the consumers. This research bases on data collection by means of a survey which was applied to 705 subjects. The data obtained has been analyzed through frequency, percentage distribution and sequence. At the end of this research it has been determined that the subjects have 10 important criteria while choosing the food and beverage establishment and the sequence of those criteria change according to demographic peculiarities of the consumers. Those ten criteria are: taste of the food, hygiene of the toilets, behaviors and the attention of the personnel, the quality of the food, freshness of the food, value for money, hygiene of the kitchen, reasonable prices, personal grooming and the appearance of the personnel, hygiene of the service equipment.
\end{abstract}

Keywords: Food and Beverage Establishments, Criteria for Preference, Expectations of Consumer

\section{Suggested Citation:}

Ertürk, M. (2018). The Criteria that Affect the Consumers' Preferences of Food and Beverage Establishments for Eating Out, Journal of Turkish Tourism Research, Vol.2, Issue.1, pp. 85-107. 


\section{Gíriş}

İnsanlığın varoluşundan beri en temel gereksinimi olan beslenme ihtiyacına bağlı yemek yeme olgusu göçebe hayattan yerleşik hayata, tarih öncesi çağlardan günümüze sürekli olarak gelişmiş ve değişmiştir. Önceleri tüccar ve seyyahlarla beliren dışarıda yemek yeme ihtiyacı, şehirleşmenin, değişen yaşam şartları ve yaşam tarzlarının etkisine paralel olarak toplumların geniş kesimlerinin ihtiyacı haline gelmiştir. Bu ihtiyacın sonucunda yiyecek işletmeleri ticari hayatta yerlerini almışlardır.

Başlangıçta sadece beslenme ihtiyacının giderilmesi beklentisi yani daha açık bir ifade ile karın doyurmak olarak karşımıza çıkan dışarıda yemek yeme olgusu; yaşam tarzlarının değişmesi, yiyecek içecek taleplerinin çeşitlenmesi, müşterilerin alım güçlerinin artması, yapılan reklam ve tavsiyelerle müşterilerde merak oluşması, müşterilerin daha sağlıklı beslenme istekleri gibi sebeplerle karın doyurmaktan öteye geçmiş, psikolojik, estetik, sosyolojik vb. kaygı ve beklentiler devreye girmiştir.

Yiyecek içecek işletmelerinin de içinde bulunduğu hizmet sektörü, müşteriyi anlamanın ve müşteriyi tatmin etmenin en zor ve karmaşık olduğu sektörlerden biridir. Hizmetin özelliği gereği soyut olması, insan odaklı olması, eş zamanlı tüketiminin gerekmesi, hizmetin standartlaştırılamaması, hizmetin değişken talep edilmesi işletmelerin işini daha da zorlaştırmaktadır.

Müşterilerin satın alma kararı ve işletme seçimlerinin temelini oluşturan beklentilerinin karşılanabilmesi için öncelikli olarak ne beklediklerini bilmek gerekmektedir. Kuşkusuz her müşterinin tüm beklentilerini bilmek ve bu beklentilerinin tamamını karşılayabilmek hizmet sektörü açısından gerçekleşmesi zor bir sonuçtur. Kişiden kişiye değişen zevkler, kişiden kişiye değişen algılar her müşteriyi yüzde yüz memnun etmeyi imkansız hale getirmektedir. Yapılacak araştırmalarla müşterilerin beklentileri doğrultusunda işletmelerin sunması gereken hizmetlerin tespit edilip sunulması müşteri memnuniyetini artıracaktır. Bu amaçla Dünya'da ve ülkemizde çok sayıda bilimsel çalışma yapılmıştır.

\section{LITERATÜR TARAMASI}

Miller ve Ginter (1979) tarafından yapılan ABD'de fast food işletmelerinde yapılan araştırmada yazarlar yemek lezzeti, servis hızı, hijyen, rahatlık, fiyat, menü çeşitliliği, çocukla gidilebilir olması kriterlerinin müşteriler için önemli olduğu sonucuna ulaşmışlardır. Bu konuda yapılan en önemli çalışmalardan biri olan Lewis (1981) tarafından ABD'de masa servisi yapılan işletmelerde gerçekleştirilen araştırmada yazar yemek kalitesi, menü çeşitliliği, atmosfer, fiyat, uygunluk kriterlerinin müşterilerin yiyecek içecek işletmesi seçiminde önemli olabileceği sonucuna ulaşmıştır. June ve Smith (1987) tarafından restoranlarda yapılan araştırmada yazarlar alkol izni bulunması, gizlilik, personelin ilgisi ve özeninin müşteriler için önemli kriterler olduğu sonucuna ulaşmışlardır. Yine bu konuda önemli çalışmalardan biri olan Auty (1992) tarafından İngiltere'de etnik restoranlarda ve publarda yapılan araştırmada yazar yemek kalitesi, yemek çeşitliliği, ödenen parayı hak etmesi, atmosfer ve konum kriterlerinin müşterilerin işletme seçiminde önemli kriterler olduğu sonucuna ulaşmıştır. Sweeney ve arkadaşları (1992) Avustralya'da öğrenciler üzerinde yaptıkları araştırmada personelin davranışları, fiyat, işletmenin hitap ettiği kitlenin araştırmaya katılan öğrenciler için önemli olduğu sonucuna ulaşmışlardır. Kara ve arkadaşlarının (1996) ABD ve Kanada'da yaptıkları fast food işletmelerinde yaptıkları araştırmada ABD'li katılımcılar için teslimat hizmeti, menü çeşitliliği, servis, yiyecek kalitesi, hijyen, anlayışlı personel, çocuklar için hediyeler, fiyat ve besin değeri kriterlerinin, Kanadalı 
katılımclar için oturma kapasitesi, hijyen, besin değeri, anlayışlı personel, fiyat, çocuklar için hediyeler ve konum kriterlerinin kendileri için önemli olduğunu belirtmişlerdir. Hsu ve arkadaşlarının (1997) Kore'de değişik türdeki yiyecek içecek işletmeleri üzerinde öğrencilerle yapmış oldukları araştırmada fast food işletmeleri için servis ekipmanlarının hijyeni, tuvalet alanı, yiyeceklerin lezzeti, personelin dış görünümü, yiyeceklerin tazeliği, personelin güler yüzlü olması, ulaşım kolaylığı, hızlı servis, yemek çeşitliliğgi kriterlerinin, masa servisi yapan işletmelerde yemeklerin lezzeti, bilinir yemekler, yemek çeşitliliği, yemeklerin sunumu, yemek porsiyonlarının doyurucu olması ve tazeliği, hijyen ve atmosferin kendileri için önemli olduğunu belirtmişlerdir. Kivela (1997) tarafından Hong Kong'da yapılan araştırmada; yiyecek içecek işletmesi seçiminde kriterlerin orada bulunma amacına göre değişebileceğini; ancak yemek kalitesi ve çeşitliliğinin en önemli kriterler olduğu tespit edilmiştir. Clark ve Wood'un (1998) restoranlar üzerine yapmış olduğu çalışmada yemeklerin çeşitliliği, yemeklerin kalitesi, yemeklerin lezzeti, fiyat, ambiyans, servis hızı kriterlerinin müşteriler için önemli kriterler olduğu tespit edilmiştir. Rumore ve arkadaşları (1999) tarafından ABD'de fast food restoranlarda öğrenciler üzerine yapılan araştırmada yiyeceklerin kalitesi, fiyat ve işletmenin konumu en önemli kriterler olarak tespit edilmiştir. Knutson (2000) tarafından 2000 yılında fast food işletmelerinde öğrenciler üzerine yapılan çalışmada hijyen, kabul edilebilirlik, fiyat, servis hızı, menüde bulunan ürünlerin tutarlılı̆̆ı önemli kriterler olarak belirlenmiştir. Azanza (2001) tarafından Filipinlerde fast food işletmeler üzerinde öğrencilerle yapılan araştırmada yemeklerin lezzeti, gida güvenliği, makul fiyat, hijyen servis hızı önemli kriterler olarak tespit edilmiştir. Park (2001) Kore'de 18-30 yaş aralığındaki müşterilerle yaptığı araştırmada yemeklerin lezzeti, hijyen, anlayışlı personel, hızlı servis kriterlerinin önemli olduğunu tespit etmiştir. Laroche ve arkadaşları (2005) Japonya' da öğrencilerle fast food işletmeleri üstüne müşterilerin markaya olan tutum ve güven seviyesinin markayı satın alma kararını etkisi konusunda bir araştırma yapmıştır. Baek ve arkadaşları (2006) yılında Kore ve Filipinlerde fast food restoranlarda öğrenciler üzerinde yaptıkları araştırmalarda Koreliler için fiyat, marka, yiyecek kalitesi, servis kalitesi ve hijyenin, Filipinliler için fiyat, yiyecek kalitesi, hijyen, servis kalitesi ve markanın, olumlu geçmiş deneyimin her iki ülke müşterisi için önemli kriterler olduğunu tespit etmiştir. Goyal ve Singh (2007) ergenlik çağındaki gençler üzerine Hindistan' da fast food işletmelerinde yaptığı araştırmada yiyecek çeşitliliği, yiyeceklerin lezzeti, yiyeceklerin kalitesi, ambiyans, hijyen, servis hızı, fiyat, konum ve diğer kişilerin tercih ediyor olmasının önemli kriterler olduğunu tespit etmiştir. Zopiatis (2007) tarafından GKRK'nde restoranlarda yapılan araştırmada hijyen, personelin tutum ve davranışları, yiyeceklerin kalitesi, personelin bilgisi, ambiyans, servisin hızı, indirim ve promosyonlar, konum, fiyat ve gizlilik önemli kriterler olarak tespit edilmiştir. Tinoco ve Riberio (2008) tarafından Brezilya'da restoran tercih eden yetişkinler üzerinde yapılan araştırmada çocuksuz çiftler için yeni tatlar denemek, arkadaş grupları için fiyat, porsiyonların doyurucu olması, yemeğin çeşidi, aileler için çocuklara ayrı alan sunması ve kolay konum, üst gelir grubu müşteriler için masaların konumu, isteklerinin karşılanması önemli kriterler olarak tespit edilmiştir. Mamalis (2009) Yunanistan'da fast food işletmeleri üzerine yaptığı araştırmada konum, yiyeceklerin kalitesi ve lezzeti, işletme tarafından sunulan hizmetler, haz alma, promosyon programları, kaliteli servis hizmeti ve ambiyansın önemli kriterler olduğunu tespit etmiştir. Tichaawa ve Mhlanga (2016) Güney Afrika'da tam servis restoranlarda yapmış oldukları araştırmada yiyecek kalitesi, servis kalitesi ve ambiyansı müşterilerin tercihinde önemli kriterler olarak tespit etmişlerdir.

Ülkemizde konu ile ilgili ilk araştırma Yüksel ve Yüksel (2003) tarafından Muğla ilinde yabancı turistler üzerinde yapılan araştırmadır. Yapılan araştırmada servis kalitesi, ürün kalitesi, hijyen, menü çeşitliliği, ödenen paranın karşılığını vermesi ve uygunluk önemli kriterler olarak tespit edilmiştir. Tayfun ve Kara (2007) tarafından Ankara'da turistik işletme belgeli 1. Sınıf 
restoranlarda yapılan araştırmada fiziki özellikler, ulaşım kolaylığı, personelin tutumu, yiyecek kalitesi, hizmetin zamanında sunulması müşterilerin önemli bulduğu kriterler olarak tespit edilmiştir. Tayfun ve Tokmak (2007) tarafında Ankara'da yerel yiyecekler sunan fast food işletmelerinde yapılan araştırmada menülerin doyurucu olması, damak tadına uygun olması, hizmetin zamanında ve hızlı olması, ulaşım kolaylığı, işyerine ve eve yakın olması kriterleri öne çıkan kriterler olarak tespit edilmiştir. Özdemir (2010) tarafından yapılan dışarıda yemek yeme olgusunun tüm yönleri ile ele alındığı ülkemizde referans kabul edilebilecek nitelikteki kuramsal çalışmada, yemek kalitesi, yemek çeşitliliği, fiyat, atmosfer/imaj, konum/uygunluk ve servisin müşterilerin işletme tercihinde göz önünde bulundurduğu önemli kriterler olduğu belirtilmiştir. Arıker (2012) tarafından İstanbul'da ikamet eden müşteriler üzerinde internet sitesi vasıtası ile yapılan araştırmada müşterilerin yiyecek içecek işletmelerinde aradıkları kriterler ile demografik özellikler arasında farklılaşma olup olmadığı araştırılmış ve farklılaşmalar olduğu tespit edilmiştir. Albayrak (2014) tarafından İstanbul'da bulunan turistik işletme belgeli restoranlarda yapılan araştırmada rahatlık, temizlik, yemeklerin kalitesi, yemeklerin çeşitliliği, yiyecek dışı hizmetler, çalışanların yetkinliği, fiyat, ödenen paranın karşılığını vermesi önemli kriterler olarak tespit edilmiştir. Yüksekbilgili (2014) tarafından İstanbul Küçükçekmece'de yapılan araştırmada servis, sunum, garsonların kıyafetleri, dış görünüş, fiyat, otopark, başkalarının tavsiyesi, çalınan müzik, sakinlik ve reklamının yapılıyor olması önemli kriterler olarak tespit edilmiştir. Karakaş ve arkadaşları (2015) tarafından Alanya'da akademisyen ve öğrenciler üzerine yapılan araştırmada yiyeceklerin kalitesi, gıda güvenliği, yiyeceklerin lezzeti, hijyen, fiyat, porsiyonların doyurucu olması, servis olanakları önemli kriterler olarak tespit edilmiştir. Karakaş ve arkadaşları tarafından Amasra'da bulunan balık restoranlarının müşterileri üzerinde yapılan araştırmada personelin özeni ve dikkati, personelin istekliliği, personelin samimiyeti, servis hızı, yiyeceklerin lezzeti, yiyeceklerin tazeliği, yiyeceklerin sunumu, restoranın isısı ve havalandırması, restoranda çalınan müzikler, kolay ulaşılabilir olması önemli kriterler olarak tespit edilmiştir. Canoğlu ve Ballı (2017) tarafından Adana'da kebap restoran müşterileri üzerinde yapılan araştırmada yiyeceklerin lezzeti, yiyeceklerin tazeliği, restoranın temizliği, ödenen paranın karşılığını vermesi, fiyatın uygunluğu önemli kriterler olarak tespit edilmiştir.

\section{YÖNTEM}

Çeşitli etkenler ile değişen yaşam şartları ve yaşam tarzları, dışarıda yeme içme olgusunu karın doyurmanın ötesine taşıyı, fizyolojik ihtiyaçların yanı sıra müşterilerin psikolojik ve sosyolojik ihtiyaçlarını giderme gereksinimlerini de bu olgunun içine katmalarına neden olmuştur. Müşterilerin değişen beklenti ve gereksinimlerini anlayıp, bunlar uygun ürün ve hizmetler sunarak müşteri memnuniyeti sağlamak işletmelerin en önemli fonksiyonlarındandır.

$\mathrm{Bu}$ araştırmada müşterilerin yiyecek içecek işletmeleri tercihinde etkili olan kriterlerin tespit edilmesi amaçlanmıştır. Bu amaçlar tespit edilirken müşterilerin demografik özelliklerine bağlı olarak aşağıdaki sorulara da yanıt aranacaktır:

- Müşterilerin yiyecek içecek işletmeleri tercihinde etkili olan kriterler yaşa göre farklılık gösterir mi?

- Müşterilerin yiyecek içecek işletmeleri tercihinde etkili olan kriterler cinsiyete göre farklılık gösterir mi?

- Müşterilerin yiyecek içecek işletmeleri tercihinde etkili olan kriterler eğitim seviyesine göre farklılık gösterir mi? 
- Müşterilerin yiyecek içecek işletmeleri tercihinde etkili olan kriterler medeni duruma göre farklılık gösterir mi?

- Müşterilerin yiyecek içecek işletmeleri tercihinde etkili olan kriterler çocuk sahipliğine göre farklıllk gösterir mi?

- Müşterilerin yiyecek içecek işletmeleri tercihinde etkili olan kriterler gelire göre farklılık gösterir mi?

- Müşterilerin yiyecek içecek işletmeleri tercihinde etkili olan kriterler dişarıda yemek yeme sıklığına göre farklılık gösterir mi?

- Müşterilerin yiyecek içecek işletmeleri tercihinde etkili olan kriterler mesleğe göre farkl1lık gösterir mi?

Araştırmada betimsel araştırma modeli kullanılmıştır. Betimsel araştırma, var olan bir olayı nicel (sayıları kullanarak) ya da nitel (bir birey ya da grubun özelliklerini ortaya koyarak) yönden betimleyen araştırma türüdür.

Araştırmanın evreni Türkiye' dir. Evrenin tamamına ulaşılamaması durumunda, veri toplanması için gereken örneklem sayısı Yamane'nin (2001) formülü ile 384 ve üstünde bir sayının yeterli olacağı tespit edilmiştir. Araştırmada 716 adet anket toplanmış, hatalı ya da eksik doldurulan 11 adet anket değerlendirmeye alınmamış, 705 adet anket değerlendirmeye alınmıştır.

Araştırmada veri toplama tekniği olarak anket yönteminden faydalanılmıştır. Anket iki bölümden oluşmaktadır. İlk bölümde yaş, cinsiyet, eğitim düzeyi, medeni durum, çocuk sahipliği, aylık gelir, dışarıda yemek yeme sıklığı ve mesleğin sorulduğu demografik bilgiler bölümden oluşmaktadır. İkinci bölümde ise literatür tarama kısmında detaylı olarak bahsedilen bugüne kadar yapılmış olan araştırmalarda kullanılan kriterlerden 48 tanesi şık şeklinde sunulmuş ve katılımcılara istedikleri kadar kriter seçebilecekleri bildirilmiştir. Sunulan kriterler alfabetik sıraya göre sıralanmıştır. Ayrıca bölüm sonuna kendi eklemek istedikleri, sunulan şıklarda bulunmayan kriter ya da kriterler varsa eklemeleri istenmiştir.

Anket formu basılı halinin bire bir ayn haliyle surveymonkey.com adlı anket oluşturma ve uygulama sitesinde de dijital olarak hazırlanmıştır. Araştırma esnasında ilgili siteden faydalanma nedenleri a) zamandan tasarruf etmek b) verilere daha hızlı ulaşmak c) anket basım maliyetinden kaçınmak d) anket dağıtma ve toplama maliyetlerinden kaçınmaktır. İlgili sitede önce bir deneme anketi oluşturulmuş, daha sonra bu anketin linki 40 kişiye gönderilerek yanıtlamaları ve yanıtladıklarını bildirmeleri istenmiştir. Yanıtlayanlara sorulardan ve şıklardan ne anladıkları sorulmuş, ifadelerde düzeltilmesi gereken noktalar tespit edilmiştir. Gerekli son düzenlemeler basılı ve dijital anket üzerinde yapılarak anket uygulamaya başlanmıştır. Dijital anketin linki Facebook isimli sosyal paylaşım sitesinde paylaşılmış ve surveymonkey.com sitesi üzerinden cevaplar toplanmıştır.

Veri toplama süreci sonunda 716 adet anket toplanmıştır. 11 adet anket eksik ya da hatalı doldurulduğu için değerlendirme dışı tutulmuş 705 adet anket değerlendirilmiştir. Uygulama alanındaki deneklerin ölçme aracına verdikleri cevapların geri dönüşümünden sonra bilgisayarda bir veri tabanı oluşturulmuştur. Araştırmadan elde edilen veriler, araştırmanın amacı doğrultusunda frekans, yüzde dağılımı ve sıralama işlemlerine tabi tutulmuştur ve yorumlanmıştır. 
Tablo 1. Araştırmaya Katılanlarla İlgili Tanıtıcı Bilgiler

\begin{tabular}{|l|c|c|}
\hline Yaş & n & \% \\
\hline 24 yaş ve altı & 94 & 13,3 \\
25-34 yaş & 177 & 25,1 \\
35-44 yaş & 235 & 33,3 \\
45-54 yaş & 153 & 21,7 \\
55-64 yaş & 41 & 5,8 \\
65 yaş ve üzeri & 5 & 0,7 \\
\hline Toplam & $\mathbf{7 0 5}$ & $\mathbf{1 0 0}$ \\
\hline & & \\
Cinsiyet & $\mathbf{n}$ & $\mathbf{9}$ \\
\hline Kadın & 292 & 41,4 \\
Erkek & 413 & 58,6 \\
\hline Toplam & $\mathbf{7 0 5}$ & $\mathbf{1 0 0}$ \\
\hline & & \\
Gelir & $\mathbf{n}$ & $\mathbf{\%}$ \\
\hline 1999 TL ve altı & 142 & 20,1 \\
2000-3999 TL arası & 250 & 35,5 \\
4000-5999 TL arası & 162 & 23 \\
6000-7999 TL arası & 80 & 11,3 \\
8000-9999 TL arası & 27 & 3,8 \\
10000 TL ve üzeri & 44 & 6,2 \\
\hline Toplam & $\mathbf{7 0 5}$ & $\mathbf{1 0 0}$ \\
\hline & & \\
& $\mathbf{n}$ & $\mathbf{\%}$ \\
\hline İlköğretim Eğitim & 17 & 2,4 \\
Lise & 136 & 19,3 \\
Önlisans & 75 & 10,6 \\
Lisans & 364 & 51,6 \\
Lisansüstü & 113 & 16 \\
\hline Toplam & $\mathbf{7 0 5}$ & $\mathbf{1 0 0}$ \\
\hline & & \\
\hline
\end{tabular}

\begin{tabular}{|l|c|c|}
\hline & & \\
Meslek & $\mathbf{n}$ & $\mathbf{\%}$ \\
\hline Öğrenci & 98 & 13,9 \\
Mavi Yakalı Çalışan & 30 & 4,3 \\
Beyaz Yakalı Çalışan & 134 & 19 \\
Serbest Meslek & 163 & 23,1 \\
Memur & 222 & 31,5 \\
Emekli & 58 & 8,2 \\
\hline Toplam & $\mathbf{7 0 5}$ & $\mathbf{1 0 0}$ \\
\hline & & \\
Medeni Durum & $\mathbf{n}$ & $\mathbf{\%}$ \\
\hline Evli & 418 & 59,3 \\
Bekar & $\mathbf{2 8 7}$ & 40,7 \\
\hline Toplam & $\mathbf{7 0 5}$ & $\mathbf{1 0 0}$ \\
\hline & & \\
Diş. Yem. Yeme Sık. & $\mathbf{n}$ & $\mathbf{\%}$ \\
\hline Yılda 1-5 kez & 38 & 5,4 \\
Yılda 6-10 kez & 41 & 5,8 \\
Ayda 1 kez & 62 & 8,8 \\
Ayda 2-5 kez & 250 & 35,5 \\
Ayda 6-9 kez & 139 & 19,7 \\
Ayda 10 kez ve üzeri & 175 & 24,8 \\
\hline Toplam & $\mathbf{7 0 5}$ & $\mathbf{1 0 0}$ \\
\hline & & \\
\multicolumn{1}{|c|}{ Çocuk Durumu } & $\mathbf{n}$ & $\mathbf{\%}$ \\
\hline Var & 410 & 58,2 \\
Yok & 295 & 41,8 \\
\hline Toplam & $\mathbf{7 0 5}$ & $\mathbf{1 0 0}$ \\
\hline
\end{tabular}

Araştırmaya katılanlara ait demografik bilgiler Tablo 1'de verilmiştir. Araştırmaya katılanların \%13,3'ü (94 katılımcı) 24 yaş ve altı, \%25,1'i (177 katılımcı) 25-34 yaş arası, \%33,3'ü (235 katılımcı) 35-44 yaş arası, \%21,7' si (153 katılımcı) 45-54 yaş arası, \%5,8' i (41 katılımcı) 55-64 yaş arası, \%0,7' si (5 katılımcı) 65 yaş ve üzeri bir yaştadır. Araştırmaya katılanların \%13,9'u (98 katılımcı) Öğrenci, \%4,3'ü (30 katılımcı) Mavi Yakalı Çalışan, \%19'u (134 katılımcı) Beyaz Yakalı Çalışan, \%23,1'i (163 katılımc1) Serbest Meslek Sahibi, \%31,5'i (222katılımc1) Memur, \%8,2'si (58 katılımc1) Emeklidir. Araştırmaya katılanların \%41,4'ü (292 katılımcı) Kadın, \%58,6'sı (413 katılımcı) Erkektir. Katılımcıların \%59,3'ü (418 katılımcı) Evli, \%40,7'si (287 katılımcı) Bekardır. Araştırmaya katılanların \%20,1'i (142 katılımcl) 1.999 TL. ve altı aylık gelire, \%35,5'i (250 katılımc1) 2.000-3.999 TL. arası aylık gelire, \%23'ü (162 katılımcı) 4.000 - 5.999 TL. arası aylık gelire, \%11,3'ü (80 
katılımcı) $6.000-7.999$ TL. arası aylık gelire, \%3,8'i (27 katılımcı) 8.000 - 9.999 TL. arası aylık gelire, \%6,2'si (44 katılımcı) 10.000 TL. ve üzeri aylık gelire sahiptir. Katılımcıların \%5,4'ü (38 katılımcı) Yılda 1-5 arası dışarıda yemek yediklerini, \%5,8'i (41 katılımcı) Yılda 6-10 kez arası dışarıda yemek yediklerini, \%8,8'i (60 katılımcı) ayda $1 \mathrm{kez}$ dışarıda yemek yediklerini, \%35,5'i (250 katılımc1) Ayda 2-5 kez arası dışarıda yemek yediklerini, \%19,7'si (139 katılımcı) Ayda 6-9 kez dışarıda yemek yediklerini, \%24,8'i (175 katılımcı) Ayda $10 \mathrm{kez}$ ve üzeri dışarıda yemek yediklerini belirtmişlerdir. Katılımcıların \%2,4'ü (17 katılımcı) İlkokul, \%19,3'ü (136 katılımcı) Lise, \%10,6'sı (75 katılımc1) Ön lisans, \% 51,6's1 (364 katılımc1) Lisans ve \%16's1 (113 katılımc1) lisansüstü mezunudur. Katılımcıların \%58,2sinin (410 katılımc1) çocuğu vardır, \%41,8'nin (295 katılımcı) çocuğu yoktur.

\section{ARAŞTIRMANIN BULGULARI}

Tabloların daha küçük boyutta hazırlanabilmesi için yer kısıtı olan durumlarda Tablo 2' deki kod tablosu kullanılmıştır.

Tablo 2. Kriter Kod Tablosu

\begin{tabular}{|c|c|c|c|c|c|}
\hline KOD & Kriter & KOD & Kriter & KOD & Kriter \\
\hline K1 & Açık Mutfak Olması & K17 & $\begin{array}{l}\text { Havalandırmasının İyi } \\
\text { Olması }\end{array}$ & K33 & Popüler olması \\
\hline K2 & Alkol Bulunmaması & K18 & Kablosuz İnternet & K34 & Porsiyonların Büyüklüğü \\
\hline K3 & Alkol Bulunması & K19 & Kalabalık Olmaması & K35 & Prestijli Bir Mekan Olması \\
\hline K4 & Ambiyansı & K20 & Maç Yayını & K36 & $\begin{array}{l}\text { Servis Alanının Hijyenik } \\
\text { Olması }\end{array}$ \\
\hline K5 & Bulunduğu Bölge & K21 & Mama Sandalyesi bulunması & K37 & $\begin{array}{l}\text { Servis Ekipmanla. Hijyenik } \\
\text { Olması }\end{array}$ \\
\hline K6 & Canlı Müzik Olması & K22 & Manzarası & K38 & Servis Şekli \\
\hline K7 & Çalınan Müzikler & K23 & $\begin{array}{l}\text { Markalı Zincir Bir İşletme } \\
\text { Olması }\end{array}$ & K39 & Servisin Hızı \\
\hline K8 & Personelin Bilgisi & K24 & Menüde Çok Çeşit Olması & K40 & Sigara Alanı Bulunması \\
\hline K9 & $\begin{array}{l}\text { Personelin İlgisi ve } \\
\text { Davranışları }\end{array}$ & K25 & Mutfağın Hijyenik Olması & K41 & Tuvaletlerin Temizliği \\
\hline K10 & $\begin{array}{l}\text { Personel Kişisel Bakım } \\
\text { ve Görünüşleri }\end{array}$ & K26 & Mutfak Türü & K42 & Ulaşımın Kolaylığı \\
\hline K11 & Çocuk Oyun Alanı & K27 & Organik Yemek Sunması & K43 & Uygun Fiyatlı Olması \\
\hline K12 & Çocuklara Özel Menü & K28 & Otoparkının Olması & K44 & Vale Hizmeti Vermesi \\
\hline K13 & Dekorasyonu & K29 & $\begin{array}{l}\text { Oturma Gruplarının Rahat } \\
\text { Olması }\end{array}$ & K45 & Yemeklerin Kalitesi \\
\hline K14 & Engellilere Uygunluğu & K30 & Ödeme Çeşitliliği & K46 & Yemeklerin Lezzeti \\
\hline K15 & Fiks Menü Hizmeti & K31 & $\begin{array}{l}\text { Ödenen Paranın Karşıllı̆ını } \\
\text { vermesi }\end{array}$ & K47 & Yemeklerin Sunum Şekli \\
\hline K16 & $\begin{array}{l}\text { Günlük Kiyafetle } \\
\text { Gidilebilmesi }\end{array}$ & K32 & Önerilmiş Olması & K48 & Yemeklerin Tazeliği \\
\hline
\end{tabular}

Araştırmaya katılanların frekans ortalamaları Tablo 3'de verilmiştir. Araştırmaya katılanların genel frekans dağılımları ve kriter sıralamaları Tablo 3'de verilmiştir. Araştırmaya katılanların 559 'u yani \%79,3'ü kendileri için en önemli kriterin Yemeklerin Lezzeti (K46) olduğunu belirtmişlerdir. Katılanların 521'i yani \%73,9'u Tuvaletlerin Temizliği (K41) kriterini en önemli ikinci kriter olarak seçmişlerdir.

Sırasıyla 516 katılımcı yani araştırmaya katılanların \%73,2'si Personelin İlgisi ve Davranışları (K9)kriterini, 507 katılımcı yani araştırmaya katılanların \%71,9'u Yemeklerin Kalitesi (K45) kriterini, 493 katılımcı yani katılımcıların \%69,9'u Yemeklerin Tazeliği kriterini 3., 4. ve 5. sıradaki 
kriter olarak seçmişlerdir. Sırasıyla 489 katılımcı yani katılımcıların \%69,4'ü Ödenen Paranın Karşılığını Vermesi (K31), 483 katılımcı yani katılımcıların \%68,5'i Mutfağın Hijyenik Olması (K25), 470 katılımcı yani katılımciların \%66,7'si Uygun Fiyatlı Olması (K43), 421 katılımcı yani katılımcıların \%59,7'si Personelin Kişisel Bakım ve Görünümleri (K10), 413 katılımcı yani katılımcıların \%58,6'sı Servis Ekipmanlarının Hijyenik Olması (K37) kriterlerini 6., 7., 8., 9. ve 10. sıradaki önemli kriter olarak belirtmişlerdir.

Tablo 3. Frekans Tablosu

\begin{tabular}{cccl|cccl}
\hline S.N. & $\mathrm{n}$ & $\%$ & Kriter & S.N. & $\mathrm{n}$ & $\%$ & Kriter \\
\hline 1 & 559 & 79,3 & Yemeklerin Lezzeti & 25 & 251 & 35,6 & Manzarası \\
2 & 521 & 73,9 & Tuvaletlerin Temizliği & 26 & 244 & 34,6 & Dekorasyonu \\
3 & 516 & 73,2 & Personelin İlgisi ve Davranışları & 27 & 240 & 34 & Çalınan Müzikler \\
4 & 507 & 71,9 & Yemeklerin Kalitesi & 28 & 232 & 32,9 & Menüde Çok Çeşit Olması \\
5 & 493 & 69,9 & Yemeklerin Tazeliği & 29 & 203 & 28,8 & Personelin Bilgisi \\
6 & 489 & 69,4 & Ödenen Paranın Karşılığını vermesi & 30 & 196 & 27,8 & Önerilmiş Olması \\
7 & 483 & 68,5 & Mutfağın Hijyenik Olması & 31 & 185 & 26,2 & Çocuk Oyun Alanı \\
8 & 470 & 66,7 & Uygun Fiyatlı Olması & 32 & 176 & 25 & Kalabalık Olmaması \\
9 & 421 & 59,7 & Personel Kişisel Bakım ve Görünüşleri & 33 & 172 & 24,4 & Açık Mutfak Olması \\
10 & 413 & 58,6 & Servis Ekipmanlarının Hijyenik Olması & 34 & 168 & 23,8 & Servis Şekli \\
11 & 403 & 57,2 & Servisin Hızı & 35 & 151 & 21,4 & Mutfak Türü \\
12 & 388 & 55 & Servis Alanının Hijyenik Olması & 36 & 144 & 20,4 & Engellilere Uygunluğu \\
13 & 360 & 51,1 & Porsiyonların Büyüklüğü & 37 & 144 & 20,4 & Kablosuz İnternet \\
14 & 351 & 49,8 & Havalandırmasının İyi Olması & 38 & 126 & 17,9 & Canlı Müzik Olması \\
15 & 346 & 49,1 & Ambiyansı & 39 & 123 & 17,4 & Organik Yemek Sunması \\
16 & 341 & 48,4 & Yemeklerin Sunum Şekli & 40 & 122 & 17,3 & Çocuklara Özel Menü \\
17 & 331 & 47 & Ödeme Çeşitliliği & 41 & 84 & 11,9 & Mama Sandalyesi bulunması \\
18 & 329 & 46,7 & Ulaşımın Kolaylı̆̆ı & 42 & 83 & 11,8 & Prestijli Bir Mekan Olması \\
19 & 324 & 46 & Bulunduğu Bölge & 43 & 77 & 10,9 & Maç Yayını \\
20 & 320 & 45,4 & Otoparkının Olması & 44 & 74 & 10,5 & Fiks Menü Hizmeti \\
21 & 298 & 42,3 & Günlük Kıyafetle Gidilebilmesi & 45 & 70 & 9,9 & Alkol Bulunmaması \\
22 & 278 & 39,4 & Alkol Bulunması & 46 & 59 & 8,4 & Popüler olması \\
23 & 253 & 35,9 & Sigara Alanı Bulunması & 47 & 47 & 6,7 & Olması Zincir Bir İletme \\
24 & 252 & 35,7 & Oturma Gruplarının Rahat Olması & 48 & 43 & 6,1 & Vale Hizmeti Vermesi \\
& & & & & & \\
\hline
\end{tabular}

İkinci on ise sırasıyla Servisin Hızı (K39) 403 katılımcı \%57,2, Servis Alanının Hijyenik Olması (K36) 388 katılımcı \%55, Porsiyonların Büyüklüğü (K34) 360 katılımcı \%51,1, Havalandırmanın İyi Olması (K17) 351 katılımcı \%49,8, Ambiyans (K4) 346 katılımcı \%49,1, Yemeklerin Sunum Şekli (K47) 341 katılımc1 \%48,4, Ödeme Çeşitliliği (K30) 331 katılımc1 \%47, Ulaşımın Kolaylığı (K42) 329 katılımcı \%46,7, Bulunduğu Bölge (K5) 324 katılımcı \%46, Otoparkının Olması (K28) 320 katılımcı \%45,4 kriterlerinden oluşmuştur.

Katılımcıların seçimleri ile son beş sırada yer alan kriterler ise sırasıyla Vale Hizmeti Vermesi (K44) 43 katılımcı \%6,1, Markalı Zincir Bir İşletme Olması (K23) 47 katılımcı \%6,7), Popüler Olması (K33) 59 katılımcı \%8,4), Alkol Bulunmaması (K2) 70 katılımcı \%9,9 ve Fiks Menü Hizmeti (K15) 74 katılımcı \%10,5 kriterleridir.

Dondurulmuş gıda kullanılmaması (1 kez), yemek esnasında aşçının yemek konusunda bilgilendirmesi (1 kez), müşteri portföyü tutularak müşterinin isteklerinin kaydedilmesi (1 kez), işletmeye güvenmem (1 kez), lezzet ve ürün standarttı (1 kez), kazıklamaması (1 kez), bakıcı hizmeti (2 kez), kendimi değerli hissettirmesi (1 kez), oyun alanının temizliği (2 kez), mama 
sandalyesinin hijyenik olması (2 kez), sos ve baharat çeşitliliği (1 kez) ankete katılanlar tarafından eklenen kriterlerdir.

\section{Demografik Değişkenlere Göre Sıralama Tabloları}

Araştırmaya katılanların yaş değişkenine göre kriter seçimleri sıralaması Tablo 4'de verilmiştir. 24 yaş ve altı katılımcılarda 82 katılımcı \%87,2 ile Yemeklerin Lezzeti (K46) kriteri ilk sırada yer alırken, 72 katılımcı \%76,6 ile Yemeklerin Kalitesi (K45) ve Yemeklerin Tazeliği (K48) kriterleri ikinci ve üçüncü sırada yer almaktadır. 24 yaş ve altı katılımcılarda Çocuk Oyun Alanı (K11) ve Vale Hizmeti Vermesi (K44) 5 katılımcı, \%5,3, Mama Sandalyesi Bulunması (K21) 4 katılımcı \%4,3 ile son üç sırada bulunan kriterlerdir. 25-34 yaş arası katılımcılarda 141 katılımcı \%79,7 ile Yemeklerin Lezzeti (K46) kriteri ilk sırada yer alırken, 132 katılımcı \%74,6 ile Ödenen Paranın Karşılı̆̆ını Vermesi (K31), 128 katılımcı \%72,3 ile Personelin İlgisi ve Davranışları (K9) ikinci ve üçüncü sırada yer almaktadır. 25-34 yaş arası katılımcılarda Fiks Menü Hizmeti (K15) ve Vale Hizmeti Vermesi (K44) 11 katılımcı, \%6,2, Markalı Zincir Bir İşletme Olması (K23) 10 katılımcı $\% 5,6$ ile son üç sırada bulunan kriterlerdir.

Tablo 4. Yaş Değişkenine Göre Araştırmaya Katılanların Kriter Sıralama Tablosu

\begin{tabular}{|c|c|c|c|c|c|c|c|c|c|c|c|c|c|c|c|c|c|c|}
\hline \multirow[b]{2}{*}{ S.N. } & \multicolumn{3}{|c|}{24 Yaş ve Altı } & \multicolumn{3}{|c|}{25 - 34 Yaş } & \multicolumn{3}{|c|}{35 - 44 Yaş } & \multicolumn{3}{|c|}{45 - 54 Yaş } & \multicolumn{3}{|c|}{55 - 64 Yaş } & \multicolumn{3}{|c|}{65 Yaş ve üzeri } \\
\hline & $\mathrm{n}$ & $\%$ & $\mathrm{~K}$ & $\mathrm{~K}$ & $\mathrm{n}$ & $\%$ & $\mathrm{n}$ & $\%$ & K & K & $\mathrm{n}$ & $\%$ & $\mathrm{n}$ & $\%$ & $\mathrm{~K}$ & $\mathrm{~K}$ & $\mathrm{n}$ & $\%$ \\
\hline 1 & 82 & 87,2 & K46 & K46 & 141 & 79,7 & 189 & 80,4 & K46 & K41 & 125 & 81,7 & 29 & 70,7 & K43 & K9 & 4 & 80,0 \\
\hline 2 & 72 & 76,6 & K45 & K31 & 132 & 74,6 & 178 & 75,7 & K9 & K46 & 121 & 79,1 & 27 & 65,9 & K25 & K25 & 4 & 80,0 \\
\hline 3 & 72 & 76,6 & K48 & K9 & 128 & 72,3 & 176 & 74,9 & K41 & K45 & 120 & 78,4 & 25 & 61,0 & K9 & K39 & 4 & 80,0 \\
\hline 4 & 71 & 75,5 & K9 & K41 & 126 & 71,2 & 173 & 73,6 & K45 & K25 & 111 & 72,5 & 25 & 61,0 & K31 & K41 & 4 & 80,0 \\
\hline 5 & 68 & 72,3 & K43 & K25 & 125 & 70,6 & 168 & 71,5 & K48 & K48 & 111 & 72,5 & 25 & 61,0 & K41 & K43 & 4 & 80,0 \\
\hline 6 & 67 & 71,3 & K31 & K48 & 117 & 66,1 & 159 & 67,7 & K25 & K9 & 110 & 71,9 & 24 & 58,5 & K28 & K22 & 3 & 60,0 \\
\hline 7 & 65 & 69,1 & K41 & K45 & 116 & 65,5 & 158 & 67,2 & K31 & K10 & 109 & 71,2 & 24 & 58,5 & K30 & K28 & 3 & 60,0 \\
\hline 8 & 63 & 67,0 & K39 & K43 & 109 & 61,6 & 153 & 65,1 & K43 & K43 & 107 & 69,9 & 24 & 58,5 & K45 & K31 & 3 & 60,0 \\
\hline 9 & 58 & 61,7 & K34 & K34 & 101 & 57,1 & 148 & 63,0 & K10 & K31 & 104 & 68,0 & 23 & 56,1 & K46 & K36 & 3 & 60,0 \\
\hline $10 \ldots$ & 57 & 60,6 & K25 & K37 & 99 & 55,9 & 147 & 62,6 & K37 & K36 & 97 & 63,4 & 22 & 53,7 & $\mathrm{~K} 37,48$ & K 46,48 & 3 & 60,0 \\
\hline$\ldots 46$ & 5 & 5,3 & K11 & K15 & 11 & 6,2 & 17 & 7,2 & K20 & K44 & 9 & 5,9 & 2 & 4,9 & $\mathrm{~K} 23,11,33$ & $\mathrm{~K} 2,3$ & 0 & 0,0 \\
\hline 47 & 5 & 5,3 & K44 & K44 & 11 & 6,2 & 16 & 6,8 & K33 & K23 & 7 & 4,6 & 1 & 2,4 & K21 & $\mathrm{K} 5,7$ & 0 & 0,0 \\
\hline 48 & 4 & 4,3 & K21 & K23 & 10 & 5,6 & 14 & 6,0 & K44 & K33 & 3 & 2,0 & 0 & 0,0 & K12 & $\mathrm{K} 23,27$ & 0 & 0,0 \\
\hline
\end{tabular}

35-44 yaş arası katılımcılarda 189 katılımcı \%80,4 ile Yemeklerin Lezzeti (K46) kriteri ilk sırada yer alırken, 178 katılımcı \%75,7 ile Personelin İlgisi ve Davranışları (K9), 176 katılımcı \%74,9 ile Tuvaletlerin Temizliği (K41) ikinci ve üçüncü sırada yer almaktadır. 35-44 yaş arası katılımcılarda Maç Yayını (K20) 17 katılımcı \%7,2 ile Popüler Olması (K33) 16 katılımcı, \%6,8 ile Vale Hizmeti Vermesi (K44) 14 katılımcı \%6 ile son üç sırada bulunan kriterlerdir. 45-54 yaş arası katılımcılarda 125 katılımcı \%81,7 ile Tuvaletlerin Temizliği (K41) kriteri ilk sırada yer alırken, 121 katılımcı \%79,1 ile Yemeklerin Lezzeti (K46), 120 katılımcı \%78,4 ile Yemeklerin Kalitesi (K45) ikinci ve üçüncü sırada yer almaktadır. 45-54 yaş arası katılımcılarda Vale Hizmeti Vermesi (K44) 9 katılımcı \%5,9 ile Markalı Zincir Bir İşletme Olması (K23) 7 katılımcı, \%4,6 ile Popüler Olması (K33) 3 katılımcı \%2 ile son üç sırada bulunan kriterlerdir. 55-64 yaş arası katılımcılarda 29 katılımcı \%70,7 ile Uygun Fiyatlı Olması (K43) kriteri ilk sırada yer alırken, 27 katılımcı \%65,9 ile Mutfağın Hijyenik Olması (K25), 25 katılımcı \%61 ile Personelin İlgisi ve Davranışları (K9) ikinci ve üçüncü sırada yer almaktadır. 55-64 yaş arası katılımcılarda Markalı Zincir Bir İşletme Olması (K23),Çocuk Oyun Alanı (K11), Popüler Olması (K33) 2 katılımcı \%4,9 ile Mama Sandalyesi Bulunması (K21) 1 katılımcı, \%2,4 ile Çocuklara Özel Menü (K12) 0 katılımcı \%0 ile son üç sırada 
bulunan kriterlerdir. 65 Yaş ve Üzeri katılımcılarda Personelin İlgisi ve Davranışları (K9), Mutfağın Hijyenik Olması (K25), Servisin Hızı (K39), Tuvaletlerin Temizliği (K41), Uygun Fiyatlı Olması (K41) kriterleri 4 katılımcı \%80 ile en çok seçilen kriterlerdir. 65 yaş ve üzeri katılımcılarda Alkol Bulunmaması (K2), Alkol Bulunması (K3), Bulunduğu Bölge (K5), Çalınan Müzikler (K7), Markalı Zincir Bir işletme Olması (K23), Organik Yemek Sunması (K27) hiç tercih edilmeyip son sirada yer alan kriterlerdir.

Araştırmaya katılanların cinsiyet değişkenine göre kriter seçimleri sıralaması Tablo 5'de verilmiştir. Araştırmaya katılan kadınlarda 252 katılımcı \%86,3 ile Yemeklerin Lezzeti (K46) kriterinin kendileri için en önemli kriter olduğunu belirtmişlerdir. 242 katılımcı \%82,9 ile Tuvaletlerin Temizliği (K41) , 235 katılımcı \% 80,5 ile Yemeklerin Tazeliğini (K48) ikinci ve üçüncü sıradaki önemli kriter olarak seçmişlerdir. Araştırmaya katılan kadınlar için 19 katılımcı \%6,5 ile Alkol Bulunmaması (K2) ve Markalı Zincir Bir İşletme Olması (K23), 7 katılımcı \%2,5 ile Maç Yayını (K20) son üç sırada bulunan kriterlerdir.

Tablo 5 Cinsiyet Değişkenine Göre Araştırmaya Katılanların Kriter Sıralama Tablosu

\begin{tabular}{|c|c|c|c|c|c|c|c|c|}
\hline \multirow[b]{2}{*}{ S.N. } & \multicolumn{4}{|r|}{ KADIN } & \multicolumn{4}{|c|}{ ERKEK } \\
\hline & $\mathrm{n}$ & $\%$ & K & Kriter & $\mathrm{K}$ & Kriter & $\mathrm{n}$ & Yüzde \\
\hline 1 & 252 & 86,3 & K46 & Yemeklerin Lezzeti & K46 & Yemeklerin Lezzeti & 307 & 74,3 \\
\hline 2 & 242 & 82,9 & K41 & Tuvaletlerin Temizliği & K9 & Personelin İlgisi ve Davranışları & 292 & 70,7 \\
\hline 3 & 235 & 80,5 & K48 & Yemeklerin Tazeliği & K45 & Yemeklerin Kalitesi & 283 & 68,5 \\
\hline 4 & 224 & 76,7 & K9 & Personelin İlgisi ve Davranışları & K41 & Tuvaletlerin Temizliği & 279 & 67,6 \\
\hline 5 & 224 & 76,7 & K45 & Yemeklerin Kalitesi & K31 & Öd. Paranın Karşılığını vermesi & 275 & 66,6 \\
\hline 6 & 223 & 76,4 & K25 & Mutfağın Hijyenik Olması & K43 & Uygun Fiyatlı Olması & 272 & 65,9 \\
\hline 7 & 214 & 73,3 & K31 & Ödenen Paranın Karşılığını Ver. & K25 & Mutfağın Hijyenik Olması & 260 & 63,0 \\
\hline 8 & 207 & 70,9 & K37 & Servis Ekip. Hijyenik Olması & K48 & Yemeklerin Tazeliği & 258 & 62,5 \\
\hline 9 & 198 & 67,8 & K43 & Uygun Fiyatlı Olması & K10 & Pers. Kiş. Bakım ve Görünüşleri & 229 & 55,4 \\
\hline $10 \ldots$ & 196 & 67,1 & K36 & Servis Alanının Hijyenik Olması & K39 & Servisin Hızı & 227 & 55,0 \\
\hline$\ldots 46$ & 19 & 6,5 & $\mathrm{~K} 2$ & Alkol Bulunmaması & K33 & Popüler olması & 39 & 9,4 \\
\hline 47 & 19 & 6,5 & K23 & Markalı Zincir Bir İşletme Olması & K23 & Markalı Zincir Bir İşletme Olması & 28 & 6,8 \\
\hline 48 & 7 & 2,4 & K20 & Maç Yayını & K44 & Vale Hizmeti Vermesi & 23 & 5,6 \\
\hline
\end{tabular}

Araştırmaya katılan erkeklerde 307 katılımcı \%74,3 ile Yemeklerin Lezzeti (K46) kriterinin kendileri için en önemli kriter olduğunu belirtmişlerdir. 292 katılımcı \%70,7 ile Personelin İlgisi ve Davranışları (K9), 283 katılımcı \%68,5 ile Yemeklerin Kalitesi (K45) ikinci ve üçüncü sıradaki önemli kriter olarak seçmişlerdir. Araştırmaya katılan erkekler için 39 katılımcı \%9,4 ile Popüler Olması (K33), 28 katılımcı \%6,8 ile Markalı Zincir Bir İşletme Olması (K23), 23 katılımcı \%5,6 ile Vale Hizmeti Vermesi (K44) son üç sırada bulunan kriterlerdir.

Araştırmaya katılanların eğitim düzeyi değişkenine göre kriter seçimleri sıralaması Tablo $6^{\prime}$ da verilmiştir. Araştırmaya katılan ilkokul mezunlarından 9 katılımcı \%52,9 ile Tuvaletlerin Temizliği (K41) ve Uygun Fiyatlı Olması (K43) kriterlerini birinci ve ikinci sırada, 8 katılımcı \%47,1 ile Ödenen Paranın Karşılığını Vermesi (K31), Yemeklerin Tazeliği (K48) kriterlerini üçüncü ve dördüncü sırada seçmişlerdir. İlkokul mezunu katılımcılarda Önerilmiş Olması (K32), Popüler Olması (K33) ve Vale Hizmeti Vermesi (K44) hiç seçilmeyerek son üç sırada yer alan kriterlerdir. Araştırmaya katılan lise mezunlarından 95 katılımcı \%69,9 ile Tuvaletlerin Temizliği (K41) kriterini ilk sırada seçmişlerdir. 93 katılımcı \%68,4 ile Yemeklerin Lezzeti (K46), 92 katılımcı \%67,6 Uygun Fiyatlı Olması (K43) kriterlerini ikinci ve üçüncü sırada önemli seçmişlerdir. Lise mezunu katılımcılarda Popüler Olması (K33) ve Prestijli Bir Mekan Olması (K35) 13 katılımcı 
\%9,6 ile Markalı Zincir Bir İşletme Olması (K23) 8 katılımcı \%5,9 ile son üç sırada yer alan kriterlerdir. Araştırmaya katılan önlisans mezunlarından 62 katılımcı \%82,7 ile Tuvaletlerin Temizliği (K41) kriterini ilk sırada seçmişlerdir. 56 katılımcı \%74,7 ile Yemeklerin Lezzeti (K46) ve Yemeklerin Tazeliği (K48) kriterlerini ikinci ve üçüncü sırada seçmişlerdir.

Tablo 6. Eğitim Düzeyi Değişkenine Göre Araştırmaya Katılanların Kriter Sıralama Tablosu

\begin{tabular}{|c|c|c|c|c|c|c|c|c|c|c|c|c|c|c|c|}
\hline \multirow[b]{2}{*}{ S.N. } & \multicolumn{3}{|c|}{ Ilköğretim } & \multicolumn{3}{|c|}{ Lise } & \multicolumn{3}{|c|}{ Önlisans } & \multicolumn{3}{|c|}{ Lisans } & \multicolumn{3}{|c|}{ Lisansüstü } \\
\hline & $\mathrm{n}$ & $\%$ & $\mathrm{~K}$ & $\mathrm{~K}$ & $\mathrm{n}$ & $\%$ & $\mathrm{n}$ & $\%$ & $\mathrm{~K}$ & $\mathrm{~K}$ & $\mathrm{n}$ & $\%$ & $\mathrm{n}$ & $\%$ & $\mathrm{~K}$ \\
\hline 1 & 9 & 52,9 & K41 & K41 & 95 & 69,9 & 62 & 82,7 & K41 & K46 & 311 & 85,4 & 92 & 81,4 & K46 \\
\hline 2 & 9 & 52,9 & K43 & K46 & 93 & 68,4 & 56 & 74,7 & K46 & K45 & 285 & 78,3 & 91 & 80,5 & K9 \\
\hline 3 & 8 & 47,1 & K31 & K43 & 92 & 67,6 & 56 & 74,7 & K48 & K9 & 280 & 76,9 & 82 & 72,6 & K31 \\
\hline 4 & 8 & 47,1 & K48 & K9 & 86 & 63,2 & 53 & 70,7 & K25 & K41 & 279 & 76,6 & 80 & 70,8 & K45 \\
\hline 5 & 7 & 41,2 & K1 & K25 & 85 & 62,5 & 53 & 70,7 & K45 & K31 & 274 & 75,3 & 77 & 68,1 & K48 \\
\hline 6 & 7 & 41,2 & K9 & K48 & 85 & 62,5 & 52 & 69,3 & K9 & K48 & 267 & 73,4 & 76 & 67,3 & K41 \\
\hline 7 & 7 & 41,2 & K10 & K45 & 84 & 61,8 & 50 & 66,7 & K31 & K25 & 266 & 73,1 & 73 & 64,6 & K25 \\
\hline 8 & 7 & 41,2 & K17 & K10 & 76 & 55,9 & 49 & 65,3 & K43 & K43 & 253 & 69,5 & 67 & 59,3 & K37 \\
\hline 9 & 7 & 41,2 & K42 & K37 & 76 & 55,9 & 44 & 58,7 & K36 & K10 & 235 & 64,6 & 67 & 59,3 & K43 \\
\hline $10 \ldots$ & 7 & 41,2 & K46 & K39 & 76 & 55,9 & 43 & 57,3 & K10,37 & K39 & 227 & 62,4 & 63 & 55,8 & K34 \\
\hline ...46 & 0 & 0,0 & K32 & K33 & 13 & 9,6 & 5 & 6,7 & $\mathrm{~K} 2,33$ & K2 & 30 & 8,2 & 9 & 8,0 & K23 \\
\hline 47 & 0 & 0,0 & K33 & K35 & 13 & 9,6 & 4 & 5,3 & K44 & K23 & 27 & 7,4 & 7 & 6,2 & K15 \\
\hline 48 & 0 & 0,0 & K44 & K23 & 8 & 5,9 & 2 & 2,7 & K23 & K44 & 21 & 5,8 & 4 & 3,5 & K 44 \\
\hline
\end{tabular}

Önlisans mezunu katılımcılarda Alkol Bulunmaması (K2) ve Popüler Olması (K33) 5 katılımcı \%6,7 ile Vale Hizmeti Vermesi (K44) 4 katılımcı \%5,3 ile Markalı Zincir Bir İşletme Olması (K23) 2 katılımcı 2,7 ile son üç sırada yer alan kriterlerdir. Araştırmaya katılan lisans mezunlarından 311 katılımcı \%85,4 ile Yemeklerin Lezzeti (K46) kriterini ilk sırada seçmişlerdir. 285 katılımcı \%78,3 ile Yemeklerin Kalitesi (K45) ve 280 katılımcı \%76,9 ile Personelin İlgisi ve Davranışları (K9) kriterlerini ikinci ve üçüncü sırada seçmişlerdir. Lisans mezunu katılımcılarda Alkol Bulunmaması (K2) 30 katılımcı \%8,2 ile Markalı Zincir Bir İşletme Olması (K23) 27 katılımcı \%7,4 ile ve Vale Hizmeti Vermesi (K44) 21 katılımcı \%5,8 ile son üç sırada yer alan kriterlerdir. Araştırmaya katılan lisansüstü mezunlarından 92 katılımcı \%81,4 ile Yemeklerin Lezzeti (K46) kriterini ilk sırada seçmişlerdir. 91 katılımcı \%80,5 ile Personelin İlgisi ve Davranışları (K9), 82 katılımcı \%72,6 ile Ödenen Paranın Karşılığını Vermesi (K31) kriterlerini ikinci ve üçüncü sırada seçmişlerdir. Lisansüstü mezunu katılımcılarda Markalı Zincir Bir İşletme Olması (K23) 9 katılımcı \%8 ile Fiks Menü Hizmeti (K15) 7 katılımcı \%6,2 ile ve Vale Hizmeti Vermesi (K44) 4 katılımcı \%3,5 ile son üç sırada yer alan kriterlerdir.

Araştırmaya katılanların medeni durum değişkenine göre kriter seçimleri sıralaması Tablo 7'de verilmiştir. Araştırmaya katılan evlilerde 332 katılımcı \%79,4 ile Yemeklerin Lezzeti (K46) kriterinin kendileri için en önemli kriter olduğunu belirtmişlerdir. 320 katılımcı \%76,6 ile Tuvaletlerin Temizliği (K41), 311 katılımc1 \%74,4 ile Yemeklerin Kalitesi (K45) ikinci ve üçüncü sırada önemli kriter olarak seçmişlerdir. Araştırmaya katılan evliler için 30 katılımcı \%7,2 ile Markalı Zincir Bir İşletme Olması (K23), 28 katılımcı \%6,7 ile Popüler Olması (K33), 27 katılımcı $\% 6,5$ ile Vale Hizmeti Vermesi (K44) son üç sırada bulunan kriterlerdir.

Araştırmaya katılan bekarlardan 227 katılımcı \%79,1 ile Yemeklerin Lezzeti (K46) kriterinin kendileri için en önemli kriter olduğunu belirtmişlerdir. 213 katılımcı \%74,2 ile Personelin İlgisi ve Davranışları (K9), 201 katılımcı \%70 ile Tuvaletlerin Temizliği (K41) ikinci ve üçüncü sırada 
önemli kriter olarak seçmişlerdir. Araştırmaya katılan bekarlar için 17 katılımcı \%5,99 ile Alkol Bulunmaması (K2) ve Markalı Zincir Bir İşletme Olması (K23), 16 katılımcı \%5,6 ile Vale Hizmeti Vermesi (K44), 14 katılımcı \%4,9 ile Mama Sandalyesi Bulunması (K21) son üç sırada bulunan kriterlerdir.

Tablo 7. Medeni Durum Değişkenine Göre Araştırmaya Katılanların Kriter Sıralama Tablosu

\begin{tabular}{|cccl|clcc}
\hline \multicolumn{9}{|c|}{ EVLI } & \multicolumn{3}{c}{ BEKAR } \\
\hline $\mathbf{n}$ & \% & K & Kriter & K & Kriter & n & $\%$ \\
\hline 332 & 79,4 & K46 & Yemeklerin Lezzeti & K46 & Yemeklerin Lezzeti & 227 & 79,1 \\
320 & 76,6 & K41 & Tuvaletlerin Temizliği & K9 & Personelin İlgisi ve Davranışları & 213 & 74,2 \\
311 & 74,4 & K45 & Yemeklerin Kalitesi & K41 & Tuvaletlerin Temizliği & 201 & 70,0 \\
303 & 72,5 & K9 & Personelin İlgisi ve Davranışları & K31 & Ödenen Paranın Kar. Vermesi & 200 & 69,7 \\
300 & 71,8 & K25 & Mutfağın Hijyenik Olması & K48 & Yemeklerin Tazeliği & 200 & 69,7 \\
293 & 70,1 & K48 & Yemeklerin Tazeliği & K45 & Yemeklerin Kalitesi & 196 & 68,3 \\
289 & 69,1 & K31 & Ödenen Paranın Karşılığını vermesi & K43 & Uygun Fiyatlı Olması & 195 & 67,9 \\
275 & 65,8 & K43 & Uygun Fiyatlı Olması & K25 & Mutfağın Hijyenik Olması & 183 & 63,8 \\
\hline 258 & 61,7 & K10 & Pers. Kişisel Bakım ve Görünüşleri & K4 & Ambiyans1 & 171 & 59,6 \\
250 & 59,8 & K37 & Servis Ekip. Hijyenik Olması 1 & K39 & Servisin Hizı & 170 & 59,2 \\
30 & 7,2 & K23 & Markalı Zincir Bir İşletme Olması & K2,23 & Al. Olmaması, M.Zin. Bir İşl. Ol. & 17 & 5,9 \\
28 & 6,7 & K33 & Popüler olması & K44 & Vale Hizmeti Vermesi & 16 & 5,6 \\
\hline 27 & 6,5 & K44 & Vale Hizmeti Vermesi & K21 & Mama Sandalyesi bulunmas1 & 14 & 4,9
\end{tabular}

Araştırmaya katılanların çocuk sahipliği değişkenine göre kriter seçimleri sıralaması Tablo 8'de verilmiştir.

Tablo 8. Çocuk Sahipliği Değişkenine Göre Araştırmaya Katılanların Kriter Sıralama Tablosu

\begin{tabular}{|c|c|c|c|c|c|c|c|c|}
\hline \multirow[b]{2}{*}{ S.N. } & \multicolumn{4}{|r|}{ VAR } & \multicolumn{4}{|c|}{ YOK } \\
\hline & $\mathrm{n}$ & $\%$ & $\mathrm{~K}$ & Kriter & $\mathrm{K}$ & Kriter & $\mathrm{n}$ & $\%$ \\
\hline 1 & 320 & 78,0 & K46 & Yemeklerin Lezzeti & K46 & Yemeklerin Lezzeti & 239 & 81,0 \\
\hline 2 & 308 & 75,1 & K41 & Tuvaletlerin Temizliği & K9 & Personelin İlgisi ve Davranışları & 234 & 79,3 \\
\hline 3 & 295 & 72,0 & K45 & Yemeklerin Kalitesi & K31 & Ödenen Paranın Kar. Vermesi & 219 & 74,2 \\
\hline 4 & 289 & 70,5 & K25 & Mutfağın Hijyenik Olması & K41 & Tuvaletlerin Temizliği & 213 & 72,2 \\
\hline 5 & 283 & 69,0 & K48 & Yemeklerin Tazeliği & K45 & Yemeklerin Kalitesi & 212 & 71,9 \\
\hline 6 & 282 & 68,8 & K9 & Personelin İlgisi ve Davranışları & K48 & Yemeklerin Tazeliği & 210 & 71,2 \\
\hline 7 & 273 & 66,6 & K43 & Uygun Fiyatlı Olması & K43 & Uygun Fiyatlı Olması & 197 & 66,8 \\
\hline 8 & 270 & 65,9 & K31 & Ödenen Paranın Karşılığını vermesi & K25 & Mutfağın Hijyenik Olması & 194 & 65,8 \\
\hline 9 & 251 & 61,2 & K10 & Personel Kişisel Bakım ve Görünüşleri & K39 & Servisin Hızı & 179 & 60,7 \\
\hline $10 \ldots$ & 243 & 59,3 & K37 & Servis Ekipmanlarının Hijyenik Olması & K4 & Ambiyansı & 176 & 59,7 \\
\hline$\ldots 46$ & 28 & 6,8 & K23 & Markalı Zincir Bir İşletme Olması & K12 & Çocuklara Özel Menü & 13 & 4,4 \\
\hline 47 & 27 & 6,6 & K44 & Vale Hizmeti Vermesi & K21 & Mama Sandalyesi bulunması & 13 & 4,4 \\
\hline 48 & 23 & 5,6 & K33 & Popüler olması & K11 & Çocuk Oyun Alanı & 12 & 4,1 \\
\hline
\end{tabular}

Araştırmaya katılan çocuk sahibi 320 katılımcı \%78 ile Yemeklerin Lezzeti (K46) kriterinin kendileri için en önemli kriter olduğunu belirtmişlerdir. 308 katılımcı \%75,1 ile Tuvaletlerin Temizliği (K41), 295 katılımcı \%72 ile Yemeklerin Kalitesi (K45) ikinci ve üçüncü sırada önemli kriter olarak seçmişlerdir. Araştırmaya katılan çocuk sahibi olanlar için 28 katılımcı \%6,8 ile 
Markalı Zincir Bir İşletme Olması (K23), 27 katılımcı \%6,6 ile Vale Hizmeti Vermesi (K44), 23 katılımcı \%5,6 ile Popüler Olması (K33), son üç sırada bulunan kriterlerdir. Araştırmaya katılan çocuk sahibi olmayan 239 katılımcı \%81 ile Yemeklerin Lezzeti (K46) kriterinin kendileri için en önemli kriter olduğunu belirtmişlerdir. 234 katılımcı \%79,3 ile Personelin İlgisi ve Davranışları (K9) , 219 katılımcı \%74,2 ile Ödenen Paranın Karşılığını Vermesi (K21) ikinci ve üçüncü sırada önemli kriter olarak seçmişlerdir. Araştırmaya katılan çocuk sahibi olmayanlar için 13 katılımcı \%4,4 ile Çocuklara Özel Menü (K12) ve Mama Sandalyesi Bulunması (K21) 12 katılımcı \%4,1 Çocuk Oyun Olanı (K11) son üç sırada bulunan kriterlerdir.

Araştırmaya katılanların aylık gelir değişkenine göre kriter seçimleri sıralaması Tablo 9'da verilmiştir. Araştırmaya katılan Aylık 1.999 TL. ve altı gelir sahibi 112 katılımcı \%78,9 ile Yemeklerin Lezzeti (K46) kriterinin kendileri için en önemli kriter olduğunu belirtmişlerdir. 107 katılımcı \%75,4 ile Personelin İlgisi ve Davranışları (K9) ve Yemeklerin Tazeliği (K48) kriterlerini ikinci ve üçüncü sırada önemli kriter olarak seçmişlerdir. Araştırmaya katılan Aylık 1.999 TL. ve altı gelir sahibi katılımcılar açısından 13 katılımcı \%9,2 ile Canlı Müzik Bulunması (K6), 11 katılımcı \%7,7 ile Markalı Zincir Bir İşletme Olması (K23), 5 katılımcı \%3,5 ile Vale Hizmeti Vermesi (K44) son üç sırada bulunan kriterlerdir. Araştırmaya katılan Aylık 2.000 - 3.999 TL. arası gelir sahibi 195 katılımcı \%78 ile Yemeklerin Lezzeti (K46) kriterinin kendileri için en önemli kriter olduğunu belirtmişlerdir. 184 katılımcı \%73,6 ile Tuvaletlerin Temizliği (K41), 181 katılımc1 \%72,4 ile Uygun Fiyatlı Olması (K43) ve Yemeklerin Kalitesi (K45) kriterlerini ikinci ve üçüncü sırada önemli kriter olarak seçmişlerdir. Araştırmaya katılan Aylık 2.000 - 3.999 TL. arası gelir sahibi katılımcılar açısından 19 katılımcı \%7,6 ile Alkol Bulunmaması (K2), 17 katılımcı \%6,8 ile Markalı Zincir Bir İşletme Olması (K23), 15 katılımcı \%6 ile Vale Hizmeti Vermesi (K44) son üç sirada bulunan kriterlerdir.

Tablo 9. Aylık Gelir Değişkenine Göre Araştırmaya Katılanların Kriter Sıralama Tablosu

\begin{tabular}{|c|c|c|c|c|c|c|c|c|c|c|c|c|c|c|c|c|c|c|}
\hline \multirow[b]{2}{*}{ S.N. } & \multicolumn{3}{|c|}{1999 TL. ve Altı } & \multicolumn{3}{|c|}{2000 - 3999 TL. } & \multicolumn{3}{|c|}{4000 - 5999 TL. } & \multicolumn{3}{|c|}{6000 - 7999 TL. } & \multicolumn{3}{|c|}{8000 - 9999 TL. } & \multicolumn{3}{|c|}{10000 TL. ve üzeri } \\
\hline & $\mathrm{n}$ & $\%$ & K & $\mathrm{K}$ & $\mathrm{n}$ & $\%$ & $\mathrm{n}$ & $\%$ & K & K & $\mathrm{n}$ & $\%$ & $\mathrm{n}$ & $\%$ & K & K & $\mathrm{n}$ & $\%$ \\
\hline 1 & 112 & 78,9 & K46 & K46 & 195 & 78,0 & 134 & 82,7 & K46 & K9 & 62 & 77,5 & 23 & 85,2 & K31 & K46 & 34 & 77,3 \\
\hline 2 & 107 & 75,4 & K9 & K41 & 184 & 73,6 & 124 & 76,5 & K41 & K41 & 62 & 77,5 & 22 & 81,5 & K41 & K9 & 31 & 70,5 \\
\hline 3 & 107 & 75,4 & K48 & K43 & 181 & 72,4 & 122 & 75,3 & K9 & K46 & 62 & 77,5 & 22 & 81,5 & K45 & K31 & 31 & 70,5 \\
\hline 4 & 104 & 73,2 & K41 & K45 & 181 & 72,4 & 121 & 74,7 & K48 & K45 & 54 & 67,5 & 22 & 81,5 & K46 & K45 & 31 & 70,5 \\
\hline 5 & 104 & 73,2 & K43 & K25 & 180 & 72,0 & 120 & 74,1 & K45 & K10 & 53 & 66,3 & 20 & 74,1 & K9 & K48 & 30 & 68,2 \\
\hline 6 & 99 & 69,7 & K45 & K31 & 177 & 70,8 & 115 & 71,0 & K25 & K25 & 53 & 66,3 & 20 & 74,1 & K28 & K25 & 27 & 61,4 \\
\hline 7 & 90 & 63,4 & K25 & K9 & 174 & 69,6 & 115 & 71,0 & K31 & K31 & 53 & 66,3 & 19 & 70,4 & K10 & K5 & 25 & 56,8 \\
\hline 8 & 90 & 63,4 & K31 & K48 & 170 & 68,0 & 105 & 64,8 & K43 & K43 & 48 & 60,0 & 18 & 66,7 & K25 & K10 & 25 & 56,8 \\
\hline 9 & 89 & 62,7 & K39 & K37 & 149 & 59,6 & 101 & 62,3 & K37 & K48 & 48 & 60,0 & 18 & 66,7 & K37 & K17 & 25 & 56,8 \\
\hline $10 \ldots$ & 79 & 55,6 & $\mathrm{~K} 10,34$ & K10 & 147 & 58,8 & 98 & 60,5 & K10 & K37 & 46 & 57,5 & 17 & 63,0 & $\mathrm{~K} 39,48$ & $\mathrm{~K} 28,37,41$ & 25 & 56,8 \\
\hline$\ldots 46$ & 13 & 9,2 & K6 & K2 & 19 & 7,6 & 9 & 5,6 & K33 & K35 & 6 & 7,5 & 1 & 3,7 & K35 & K2 & 3 & 6,8 \\
\hline 47 & 11 & 7,7 & K23 & K23 & 17 & 6,8 & 6 & 3,7 & K44 & K15 & 5 & 6,3 & 0 & 0,0 & K15 & K15 & 3 & 6,8 \\
\hline 48 & 5 & 3,5 & K44 & K44 & 15 & 6,0 & 5 & 3,1 & K23 & K33 & 3 & 3,8 & 0 & 0,0 & K33 & K33 & 2 & 4,5 \\
\hline
\end{tabular}

Araştırmaya katılan Aylık 4.000 - 5.999 TL. arası gelir sahibi 134 katılımcı \%82,7 ile Yemeklerin Lezzeti (K46) kriterinin kendileri için en önemli kriter olduğunu belirtmişlerdir. 124 katılımc1 \%76,5 ile Tuvaletlerin Temizliği (K41), 122 katılımcı \%75,3 ile Personelin İlgisi ve Davranışları (K9) kriterlerini ikinci ve üçüncü sırada önemli kriter olarak seçmişlerdir. Araştırmaya katılan Aylık 4.000 - 5.999 TL. arası gelir sahibi katılımcılar açısından 9 katılımcı \%5,6 ile Popüler Olması (K33), 6 katılımcı \%3,7 ile Vale Hizmeti Vermesi (K44), 5 katılımcı \%3,1 ile Markalı Zincir Bir İşletme Olması (K23) son üç sırada bulunan kriterlerdir. Araştırmaya katılan Aylık 6.000 - 7.999 
TL. arası gelir sahibi 62 katılımcı \%,77,5 ile Personelin İlgisi ve Davranışları (K9), Tuvaletlerin Temizliği (K41), Yemeklerin Lezzeti (K46) kriterlerinin kendileri için en önemli üç kriter olduğunu belirtmişlerdir. Aylık 6.000 - 7.999 TL. arası gelir sahibi katılımcılar açısından 6 katılımcı \%7,5 ile Prestijli Bir Mekan Olması (K35), 5 katılımc1 \%6,3 ile Fiks Menü Hizmeti (K15), 3 katılımcı \%3,8 ile Popüler Olması (K33) son üç sırada bulunan kriterlerdir. Araştırmaya katılan Aylık 8.000 - 9.999 TL. arası gelir sahibi 23 katılımcı \%85,2 ile Ödenen Paranın Karşılığını Vermesi (K31) kriterinin kendileri için en önemli kriter olduğunu belirtmişlerdir. 22 katılımcı \% 81,5 ile Tuvaletlerin Temizliği (K41), Yemeklerin Kalitesi (K45), Yemeklerin Tazeliği (K46) kriterlerinin ikinci ve üçüncü sırada önemli kriter olarak seçmişlerdir. Araştırmaya katılan Aylık 8.000 - 9.999 TL. arası gelir sahibi katılımcılar açısından 1 katılımcı \%3,7 ile Prestijli Bir Mekan Olması (K35), 0 katılımcı ile Fiks Menü Hizmeti (K15) ve Popüler Olması (K33) son üç sırada bulunan kriterlerdir. Araştırmaya katılan Aylık 10.000 TL. ve üzeri gelir sahibi 34 katılımcı \%77,3 ile Yemeklerin Lezzeti (K46) kriterinin kendileri için en önemli kriter olduğunu belirtmişlerdir. 31 katılımcı \%70,5 ile Personelin İlgisi ve Davranışları (K9), Ödenen Paranın Karşılığını Vermesi (K31) Yemeklerin Kalitesi (K45) kriterlerini ikinci ve üçüncü sırada önemli kriterler olarak seçmişlerdir. Araştırmaya katılan Aylık 10.000 TL. ve üzeri gelir sahibi katılımcılar açısından 3 katılımcı \%6,8 ile Alkol Bulunmaması (K2) ve Fiks Menü Hizmeti (15), 2 katılımcı \%4,5 ile Popüler Olması (K33) son üç sırada bulunan kriterlerdir.

Araştırmaya katılanların dışarıda yeme sıklığı değişkenine göre kriter seçimleri sıralaması Tablo 10 'da verilmiştir. Araştırmaya katılan Yılda 1-5 kez arası dışarıda yemek yiyen 27 katılımcı $\% 71,1$ ile Tuvaletlerin Temizliği (K41) kriterinin kendileri için en önemli kriter olduğunu belirtmişlerdir. 24 katılımcı \%63,2 ile Personelin İlgisi ve Davranışları (K9), Yemeklerin Kalitesi (K45), Yemeklerin Lezzeti (K46) ve Yemeklerin Tazeliği (K48) kriterlerini ikinci ve üçüncü sırada önemli kriter olarak seçmişlerdir.

Tablo 10. Dışarıda Yemek Yeme Sıklığı Değişkenine Göre Araştırmaya Katılanların Kriter Siralama Tablosu

\begin{tabular}{|c|c|c|c|c|c|c|c|c|c|c|c|c|c|c|c|c|c|c|}
\hline \multirow[b]{2}{*}{ S.N. } & \multicolumn{3}{|c|}{ YILDA 1-5 } & \multicolumn{3}{|c|}{ YILDA 6-10 } & \multicolumn{3}{|c|}{ AYDA 1} & \multicolumn{3}{|c|}{ AYDA 2-5 } & \multicolumn{3}{|c|}{ AYDA 6-9 } & \multicolumn{3}{|c|}{$\begin{array}{c}\text { AYDA10 } \\
\text { UZERI }\end{array}$} \\
\hline & $\mathrm{n}$ & $\%$ & $\mathrm{~K}$ & $\mathrm{~K}$ & $\mathrm{n}$ & $\%$ & $\mathrm{n}$ & $\%$ & $\mathrm{~K}$ & $\mathrm{~K}$ & $\mathrm{n}$ & $\%$ & $\mathrm{n}$ & $\%$ & $\mathrm{~K}$ & $\mathrm{~K}$ & $\mathrm{n}$ & $\%$ \\
\hline 1 & 27 & 71,1 & K41 & K9 & 30 & 73,2 & 47 & 75,8 & K25 & K46 & 200 & 80,0 & 121 & 87,1 & K46 & K46 & 141 & 80,6 \\
\hline 2 & 24 & 63,2 & K9 & K25 & 29 & 70,7 & 46 & 74,2 & K46 & K41 & 189 & 75,6 & 106 & 76,3 & K9 & K9 & 132 & 75,4 \\
\hline 3 & 24 & 63,2 & K45 & K41 & 27 & 65,9 & 45 & 72,6 & K41 & K45 & 188 & 75,2 & 106 & 76,3 & K41 & K45 & 130 & 74,3 \\
\hline 4 & 24 & 63,2 & K46 & K46 & 27 & 65,9 & 44 & 71,0 & K43 & K25 & 186 & 74,4 & 104 & 74,8 & K31 & K41 & 127 & 72,6 \\
\hline 5 & 24 & 63,2 & $\mathrm{~K} 48$ & K43 & 26 & 63,4 & 44 & 71,0 & K45 & K31 & 182 & 72,8 & 101 & 72,7 & K48 & K31 & 122 & 69,7 \\
\hline 6 & 23 & 60,5 & $\mathrm{~K} 25$ & K10 & 25 & 61,0 & 44 & 71,0 & K48 & K9 & 181 & 72,4 & 99 & 71,2 & K45 & K48 & 119 & 68,0 \\
\hline 7 & 23 & 60,5 & K43 & K37 & 25 & 61,0 & 43 & 69,4 & K9 & K48 & 180 & 72,0 & 93 & 66,9 & K43 & K43 & 111 & 63,4 \\
\hline 8 & 21 & 55,3 & K10 & K48 & 25 & 61,0 & 41 & 66,1 & K31 & K43 & 173 & 69,2 & 92 & 66,2 & K25 & K10 & 108 & 61,7 \\
\hline 9 & 20 & 52,6 & K34 & K31 & 23 & 56,1 & 39 & 62,9 & K36 & K39 & 163 & 65,2 & 82 & 59,0 & K37 & K25 & 106 & 60,6 \\
\hline $10 \ldots$ & 19 & 50,0 & K30,39 & K45 & 22 & 53,7 & 38 & 61,3 & $\mathrm{~K} 10,37$ & K37 & 152 & 60,8 & 80 & 57,6 & & K4 & 102 & 58,3 \\
\hline$\ldots 46$ & 2 & 5,3 & $\mathrm{~K} 23,35$ & K20 & 3 & 7,3 & 3 & 4,8 & K44 & K33 & 20 & 8,0 & 11 & & & K15 & 16 & 9,1 \\
\hline 47 & 1 & 2,6 & K44 & K44 & 2 & 4,9 & 2 & 3,2 & K20 & K44 & 15 & 6,0 & 9 & & & K23 & 16 & 9,1 \\
\hline 48 & 0 & 0,0 & K33 & K23 & 0 & 0,0 & 1 & 1,6 & K33 & K23 & 13 & 5,2 & 4 & 2,9 & K44 & K2 & 10 & 5,7 \\
\hline
\end{tabular}

Araştırmaya katılan Yılda 1-5 kez arası dışarıda yemek yiyen katılımcılar açısından 6 katılımcı \%6,1 ile Canlı Müzik Bulunması (K6), 5 katılımcı \%5,1 ile Alkol Bulunmaması (K2), 4 katılımcı $\% 4,1$ ile Vale Hizmeti Vermesi (K44) son üç sırada bulunan kriterlerdir. Araştırmaya katılan Yılda 6-10 kez arası dışarıda yemek yiyen 30 katılımcı \%73,2 ile Personelin İlgisi ve Davranışları (K9) kriterinin kendileri için en önemli kriter olduğunu belirtmişlerdir. 29 katılımcı \%70,7 ile Mutfağın 
Hijyenik Olması (K25) kriterinin ikinci sırada, 27 katılımcı \%65,9 ile Tuvaletlerin Temizliği (K41) ve Yemeklerin Lezzeti (K46) üçüncü sırada önemli kriter olarak seçmişlerdir. Araştırmaya katılan Yılda 6-10 kez arası dışarıda yemek yiyen katılımcılar açısından 3 katılımcı \%7,3 ile Maç Yayını (K20), 2 katılımcı \%4,9 ile Vale Hizmeti Vermesi (K44) 0 katılım ile Markalı ve Zincir Bir İşletme Olması (K23) son üç sırada bulunan kriterlerdir. Araştırmaya katılan Ayda 1 kez dışarıda yemek yiyen 47 katılımcı \%75,8 ile Mutfağın Hijyenik Olması (K25) kriterinin kendileri için en önemli kriter olduğunu belirtmişlerdir. 46 katılımc \%74,2 ile Yemeklerin Lezzeti (K46) kriterinin ikinci sırada, 45 katılımcı \%72,6 ile Tuvaletlerin Temizliği (K41) kriterini üçüncü sırada seçmişlerdir. Araştırmaya katılan Ayda 1 kez dışarıda yemek yiyen katılımcılar açısından 3 katılımcı \%4,8 ile Vale Hizmeti Vermesi (K44), 2 katılımcı \%3,2 ile Maç Yayını (K20), 1 katılımcı \%1,6 ile Popüler Olması (K33) son üç sırada bulunan kriterlerdir. Araştırmaya katılan Ayda 2-5 kez arası dışarıda yemek yiyen 200 katılımcı \%80 ile Yemeklerin Lezzeti (K46) kriterinin kendileri için en önemli kriter olduğunu belirtmişlerdir. 189 katılımcı \%75,6 ile Tuvaletlerin Temizliği (K41) kriterini ikinci sırada, 188 katılımcı \%75,2 ile Yemeklerin Kalitesi (K45) kriterini üçüncü sırada seçmişlerdir. Araştırmaya katılan Ayda 2-5 kez arası dışarıda yemek yiyen katılımcılar açısından 20 katılımcı \%8 ile Popüler Olması (K33), 15 katılımcı \%6 ile Vale Hizmeti Vermesi (K44), 13 katılımcı \%5,2 ile Markalı ve Zincir Bir İşletme Olması (K23) kriterleri son üç sırada bulunan kriterlerdir. Araştırmaya katılan Ayda 6-9 kez arası dışarıda yemek yiyen 121 katılımcı \%87,1 ile Yemeklerin Lezzeti (K46) kriterinin kendileri için en önemli kriter olduğunu belirtmişlerdir. 106 katılımcı \%76,3 ile Personelin İlgisi ve Davranışları (K9) ve Tuvaletlerin Temizliği (K41) kriterlerini ikinci ve üçüncü sırada seçmişlerdir. Araştırmaya katılan Ayda 6-9 kez arası dışarıda yemek yiyen katılımcılar açısından 11 katılımcı \%7,9 ile Markalı ve Zincir Bir İşletme Olması (K23), 9 katılımc1 \%6,5 ile Alkol Bulunmaması (K2), 4 katılımcı \%2,9 ile Vale Hizmeti Vermesi (K44), kriterleri son üç sırada bulunan kriterlerdir. Araştırmaya katılan Ayda 10 kez ve üzeri dışarıda yemek yiyen 141 katılımcı \%80,6 ile Yemeklerin Lezzeti (K46) kriterinin kendileri için en önemli kriter olduğunu belirtmişlerdir. 132 katılımcı \%75,4 ile Personelin İlgisi ve Davranışları (K9) ve 130 katılımcı \%74,3 ile Yemeklerin Kalitesi (K45) kriterlerini ikinci ve üçüncü sırada seçmişlerdir. Araştırmaya katılan Ayda $10 \mathrm{kez}$ ve üzeri dışarıda yemek yiyen katılımcılar açısından 16 katılımcı \%9,1 ile Fiks Menü Hizmeti (K15) ve Markalı ve Zincir Bir İşletme Olması (K23), 10 katılımcı \%5,7 ile Alkol Bulunmaması (K2) kriterlerini son üç sırada bulunan kriterler olarak belirtmişlerdir.

Araştırmaya katılanların meslek değişkenine göre kriter seçimleri sıralaması Tablo 11'de verilmiştir. Araştırmaya katılan öğrencilerden 83 katılımcı \%84,7 ile Yemeklerin Lezzeti (K46) kriterinin kendileri için en önemli kriter olduğunu belirtmişlerdir. 74 katılımcı \%75,5 ile Yemeklerin Kalitesi (K45) kriterinin ikinci sırada, 73 katılımcı \%74,5 ile Personelin İlgisi ve Davranışları (K9) ve Yemeklerin Tazeliği (K48) kriterlerini üçüncü sırada önemli kriter olarak seçmişlerdir. Araştırmaya katılan öğrenciler açısından 6 katılımcı \%6,1 ile Canlı Müzik Bulunması (K6), 5 katılımcı \%5,1 ile Alkol Bulunmaması (K2), 4 katılımcı \%4,1 ile Vale Hizmeti Vermesi (K44) kriterleri son üç sırada bulunan kriterlerdir. Araştırmaya katılan mavi yakalı çalışanlardan 20 katılımcı \%66,7 ile Yemeklerin Lezzeti (K46) kriterinin kendileri için en önemli kriter olduğunu belirtmişlerdir. 19 katılımcı \%63,3 ile Bulunduğu Bölge (K5), Günlük Kıyafetle Gidilebilmesi (K16), Tuvaletlerin Temiz Olması (K41) kriterlerini ikinci ve üçüncü sırada önemli kriter olarak seçmişlerdir. Araştırmaya katılan mavi yakalı çalışanlar açısından 3 katılımcı \%10 ile Organik Yemek Sunması (K27), 2 katılımcı \%6,7 ile 0 katılımc ile Vale Hizmeti Vermesi (K44) kriterleri son üç sırada bulunan kriterlerdir. 
Tablo 11. Meslek Değişkenine Göre Araştırmaya Katılanların Kriter Sıralama Tablosu

\begin{tabular}{|c|c|c|c|c|c|c|c|c|c|c|c|c|c|c|c|c|c|c|}
\hline \multirow[b]{2}{*}{ S.N. } & \multicolumn{3}{|c|}{ Öğrenci } & \multicolumn{3}{|c|}{ Mavi Yaka } & \multicolumn{3}{|c|}{ Beyaz Yaka } & \multicolumn{3}{|c|}{ Ser. Mes. } & \multicolumn{3}{|c|}{ Memur } & \multicolumn{3}{|c|}{ Emekli } \\
\hline & $\mathrm{n}$ & $\%$ & K & $\mathrm{K}$ & $\mathrm{n}$ & $\%$ & $\mathrm{n}$ & $\%$ & $\mathrm{~K}$ & K & $\mathrm{n}$ & $\%$ & $\mathrm{n}$ & $\%$ & K & $\mathrm{K}$ & $\mathrm{n}$ & $\%$ \\
\hline 1 & 83 & 84,7 & K46 & K46 & 20 & 66,7 & 108 & 80,6 & K46 & K41 & 125 & 76,7 & 184 & 82,9 & K46 & K43 & 46 & 79,3 \\
\hline 2 & 74 & 75,5 & K45 & K5 & 19 & 63,3 & 103 & 76,9 & K9 & K46 & 124 & 76,1 & 176 & 79,3 & K9 & K41 & 43 & 74,1 \\
\hline 3 & 73 & 74,5 & K9 & K16 & 19 & 63,3 & 99 & 73,9 & K31 & K48 & 118 & 72,4 & 174 & 78,4 & K25 & K25 & 42 & 72,4 \\
\hline 4 & 73 & 74,5 & K48 & K41 & 19 & 63,3 & 94 & 70,1 & K45 & K45 & 108 & 66,3 & 174 & 78,4 & K45 & K45 & 42 & 72,4 \\
\hline 5 & 72 & 73,5 & K43 & $\mathrm{K} 4$ & 18 & 60,0 & 93 & 69,4 & K41 & K9 & 107 & 65,6 & 173 & 77,9 & K41 & K9 & 41 & 70,7 \\
\hline 6 & 68 & 69,4 & K41 & K25 & 18 & 60,0 & 85 & 63,4 & K48 & K31 & 103 & 63,2 & 170 & 76,6 & K31 & K46 & 40 & 69,0 \\
\hline 7 & 66 & 67,3 & K31 & K34 & 17 & 56,7 & 84 & 62,7 & K25 & K25 & 102 & 62,6 & 163 & 73,4 & K48 & K48 & 39 & 67,2 \\
\hline 8 & 63 & 64,3 & K25 & K43 & 17 & 56,7 & 82 & 61,2 & K37 & K43 & 101 & 62,0 & 156 & 70,3 & K43 & K31 & 35 & 60,3 \\
\hline 9 & 61 & 62,2 & K5 & K9,10,28 & 16 & 53,3 & 78 & 58,2 & K39 & K37 & 94 & 57,7 & 151 & 68,0 & K10 & K39 & 35 & 60,3 \\
\hline $10 \ldots$ & 60 & 61,2 & K39 & $\mathrm{K} 30,31,42$ & 16 & 53,3 & 78 & 58,2 & K43 & K10 & 92 & 56,4 & 145 & 65,3 & $\mathrm{~K} 36,37$ & $\mathrm{~K} 10,30$ & 33 & 56,9 \\
\hline$\ldots 46$ & 6 & 6,1 & K6 & K27 & 3 & 10,0 & 10 & 7,5 & K23 & K33 & 14 & 8,6 & 11 & 5,0 & K20 & K21 & 3 & 5,2 \\
\hline 47 & 5 & 5,1 & K2 & K23 & 2 & 6,7 & 6 & 4,5 & K44 & K15 & 11 & 6,7 & 11 & 5,0 & K44 & K23 & 3 & 5,2 \\
\hline 48 & 4 & 4,1 & K44 & K44 & 0 & 0,0 & 5 & 3,7 & $\mathrm{~K} 2$ & K23 & 11 & 6,7 & 10 & 4,5 & K33 & K33 & 3 & 5,2 \\
\hline
\end{tabular}

Araştırmaya katılan beyaz yakalı çalışanlardan 108 katılımcı \%80,6 ile Yemeklerin Lezzeti (K46) kriterinin kendileri için en önemli kriter olduğunu belirtmişlerdir. 103 katılımcı \%76,9 ile Personelin İlgisi ve Davranışları (K9), 99 katılımcı \%73,9 ile Ödenen Paranın Karşılığını Vermesi (K31) kriterlerini ikinci ve üçüncü sırada seçmişlerdir. Araştırmaya katılan beyaz yakalı çalışanlar açısından 10 katılımcı \%7,5 ile Markalı Zincir Bir İşletme Olması (K23), 6 katılımcı \%4,5 ile Vale Hizmeti Vermesi (K44), 5 katılımcı \%3,7 ile Alkol Bulunmaması (K2), kriterleri son üç sırada bulunan kriterlerdir. Araştırmaya katılan serbest meslek sahiplerinden 125 katılımcı \%76,7 ile Tuvaletlerin Temiz Olması (K41) kriterinin kendileri için en önemli kriter olduğunu belirtmişlerdir. 124 katılımcı \%76,1 ile Yemeklerin Lezzeti (K46) kriterinin ikinci sırada, 118 katılımcı \%72,4 ile Yemeklerin Tazeliği (K48) kriterinin üçüncü sırada önemli kriter olduğunu belirtmişlerdir. Araştırmaya katılan serbest meslek sahipleri açısından 14 katılımcı \%8,6 ile Popüler Olması (K33), 11 katılımcı \%6,7 ile Fiks Menü Hizmeti (K15) ve Markalı Zincir Bir İşletme Olması (K23, kriterleri son üç sırada bulunan kriterlerdir. Araştırmaya katılan memurlardan 184 katılımcı \%82,9 ile Yemeklerin Lezzeti (K46) kriterinin kendileri için en önemli kriter olduğunu belirtmişlerdir. 176 katılımcı \%79,3 ile Personelin İlgisi ve Davranışları (K9) kriterinin ikinci sırada, 174 katılımcı \%78,4 ile Mutfağın Hijyenik Olması (K25) ve Yemekleri Kalitesi (K45) kriterlerinin üçüncü sırada önemli kriter olduğunu belirtmişlerdir. Araştırmaya katılan memurlar açısından 11 katılımcı \%5 ile Maç Yayını (K20) ve Vale Hizmeti Vermesi (K44), 10 katılımcı \%4,5 ile Popüler Olması (K33) kriterleri son üç sırada bulunan kriterlerdir. Araştırmaya katılan emeklilerden 46 katılımcı \%79,3 ile Uygun Fiyatlı Olması (K43) kriterinin kendileri için en önemli kriter olduğunu belirtmişlerdir. 43 katılımcı \%74,1 ile Tuvaletlerin Temiz Olması (K41) kriterinin ikinci, 42 katılımcı \%72,4 ile Mutfağın Hijyenik Olması (K25) ve Yemekleri Kalitesi (K45) kriterlerinin üçüncü sırada önemli kriterler olduğunu belirtmişlerdir. Araştırmaya katılan emekliler açısından 3 katılımcı \%5,2 ile Mama Sandalyesi Bulunması (K21), Markalı Zincir Bir İşletme Olması (K23) ve Popüler Olması (K33) kriterleri son üç sırada bulunan kriterlerdir.

\section{SONUÇ VE ÖNERILER}

Birer hizmet işletmesi olan yiyecek içecek işletmelerinin başarıları müşterilerinin beklentilerini mümkün olan en üst düzeyde karşılamaları ile ölçülebilmektedir. Başka bir ifade ile sundukları 
hizmetin kalitesi müşterilerinin algı düzeyleri ile doğrudan ilişkilidir. Müşterilerin beklentilerini oluşturan kriterleri tespit etmek yiyecek içecek işletmelerinin sürdürülebilirliği açısından önemli bir noktadır.

Araştırmada bu noktadan yola çıkarak müşterilerin yiyecek içecek işletmesi seçerken göz önünde bulundurduğu kriterler tespit edilmeye çalışılmıştır. Buna göre sırasıyla yemeklerin lezzeti, tuvaletlerin temizliği, personelin ilgisi ve davranışları, yemeklerin kalitesi, yemeklerin tazeliği, ödenen paranın karşılığını vermesi, mutfağın hijyenik olması, uygun fiyatlı olması, personelin kişisel bakımı ve görünüşleri, servis ekipmanlarının hijyenik olması araştırmaya katılanlar tarafından yiyecek içecek işletmesi seçiminde göz önünde bulundurdukları 10 önemli kriterdir.

İlk 10 kriter sıralaması bu şekilde oluşmuş olsa da geride kalan diğer kriterler de azımsanmayacak oranda katılımcılar tarafından tercih edilmiştir. Servisin hızı, servis alanlarının hijyenik olması, porsiyonların büyüklüğü, havalandırmanın iyi olması, ambiyans, yemeklerin sunum şekli, ödeme çeşitliliği, ulaşımın kolaylığı, bulunduğu bölge, otoparkının olması, günlük kıyafetlerle gidilebilmesi seçenekleri \%40'ın üzerinde tercih edilen kriterlerdir. İşletmelerin sıralanan bu kriterleri işletmenin olmazsa olmazları olarak kabul etmesi işletme açısından faydalı olacaktır. Daha düşük oranda seçilmiş olan kriterlere sahip olmak ise işletmeye ek bir doluluk getirip rakiplerinden ayrılmasına neden olacaktır.

Yemeklerin lezzeti, yemeklerin kalitesi, yemeklerin tazeliği kriterlerinin ilk 5 kriter içinde yer alması müşterilerin ürün kalitesi konusunda çok hassas olduğunu göstermektedir. İşletmeler müşterilerine sundukları yemeklerde ürün kalitesini her zaman ön planda tutmak zorundadırlar. Şayet müşterilerinize lezzetli, taze, kaliteli yiyecekler sunamıyorsanız ambiyansa, dekora, manzaraya harcayacağınız paraların karşılığını almanız, işletmenizi yaşamını sürdürülebilmeniz mümkün değildir. Ödenen paranın karşılığını vermesi kriterinin uygun fiyatlı olmasından daha çok tercih edilen bir kriter olması müşterinin kaliteli yiyecekler için daha fazla ödemeyi göze aldığ 1 şeklinde yorumlanabilir. Ancak burada dikkat edilmesi gereken husus alınan paranın hem ürün kalitesi hem hizmet kalitesi olarak tam karşllı̆ıının verilmesidir. Bu başarılamazsa müşteri kendini kandırılmış ve kazıklanmış hissedeceğinden bir daha aynı işletmeyi tercih etmeyip, başka alternatifleri değerlendirecektir.

Tuvaletlerin temizliği, mutfağın hijyenik olması, personelin kişisel bakım ve görünüşü, servis ekipmanlarının hijyenik olması müşterilerin hijyenik şartlara karşı da son derece duyarlı olduğunun göstergesidir. En iyi dekorla, en iyi malzeme ile en kaliteli yemeği de sunuyor olsanız zemindeki bir kir, bardaktaki bir ruj lekesi, çatal kaşıklardaki lekeler, masa örtüsündeki bir yağ lekesi müşterinin işletmeye karşı bakışını değiştirmeye yetecektir. Hijyen ve temizlik yiyecek içecek işletmelerinin hem müşteri sağlı̆̆ı hem de işletmenin geleceği açısından boş veremeyecekleri kadar önemli bir husustur.

Personelin ilgisi ve davranışları, personelin kişisel bakım ve görünüşleri kriterlerinin üst sıralarda yer alması, işletmenin personel kalitesinin, manzarasından, dekorasyonundan çok daha önemli olduğunun altını çizmektedir. İşletmeler en iyi mekanları müşteriye hazırlasalar dahi iyi hizmet edecek insan gücüne sahip değillerse istedikleri başarıya ulaşmaları mümkün değildir. $\mathrm{Bu}$ yüzden işletmeler ucuz, işi bilmeyen personel yerine işini seven, işini iyi bilen, müşteriye yapabildiğinin en iyisini yapmaya çalışan personel istihdamına öncelik vermelidir. Fiziki şartlara yaptıkları yatırım gibi bu alana da gereken yatırımları yaptıkları takdirde karşılığını fazlası ile alacaklardır. Müşterinin beklentisi temiz ve hijyenik bir ortamda ödediği paranın karşıllı̆̆ iyi bir 
yemek, biraz samimiyet, biraz ilgidir özet olarak. Bunları sağlamanın birinci koşulu da iyi personel istihdam etmekten geçer.

Araştırma sonucu müşterilerin demografik özellikleri ile yiyecek içecek işletmeleri seçiminde göz önünde bulundurdukları kriterler arasında farklar vardır. Farkların yer aldığı demografik özellikler ve kriter sıralama listesi eklerde sunulmuş, ortalamaya göre oluşan farklar gri renkle gösterilmiştir.

Araştırmada çocuk sahibi olduğunu belirten katılımcılara çocuklarının yaşları sorulmamıştır. Ancak 25-34 ve 35-44 yaş grubu katılımcıların çocuklarının yaşlarının 12 yaş altı olduğu tahmini yapılabilir. Bu yaş guruplarına ait çocuk sahibi olduğunu belirten 234 katılımcının Çocuk Oyun Alanı Kriterini seçme sayısı 138, seçme oranı ise $\% 58,9^{\prime}$ dur. Oysa genel sıralamada Çocuk Oyun Alanı kriterinin seçilme oranı \%26,2'dir. Çocuklara Özel Menü kriterinin genel sıralamada seçilme oranı \%17,3 iken 25-44 yaş arası çocuk sahibi 234 katılımcıda seçilme oranı \% 34,6, seçen kişi sayısı 81'dir. Mama Sandalyesi kriteri genel sıralamada \%11,9 iken 25-44 yaş arası çocuk sahibi katılımcılarda \%25,6 oranında 60 kişi tarafından seçilmiştir. Kaldı ki mama sandalyesi genellikle çocuğun 3 yaşını doldurana kadar kullanıldığı düşünüldüğünde bu oran sadece 3 yaş altı çocuk sahiplerine yönelik bir araştırmada çok daha fazla yükselecektir. Yani 25-44 yaş arası çocuk sahibi katılımcılar çocuklarla ilgili kriterleri normalin iki katı üstünde seçmişlerdir. Bu sonuç çocuklu ailelerin beklentilerinin diğer gruplara göre farklılık gösterdiğini işaret etmektedir ve bu farklılı̆̆ın ilerideki çalışmalarda ayrıntılı olarak araştırılması gerekmektedir.

\section{KAYNAKÇA}

Albayrak, A. (2014). "Müşterilerin Restoran Seçimini Etkileyen Faktörler, İstanbul Örneği", Anatolia: Turizm Araştırmaları Dergisi, 25(2):190-201.

Arıker, Ç. (2012). “Tüketicilerin Restoran Seçiminde Kullandıkları Seçim Kriterleri ile Demografik Özellikleri Arasındaki İlişki", Marmara Üniversitesi Sosyal Bilimler Enstitüsü Öneri Dergisi, 10(38): 11-31

Auty, S. (1992). "Consumer Choice and Segmentation in The Restaurant Industry", The Service Industries Journal, 12(3):324-339.

Azanza, P. V. (2001). "Food Consumption and Buying Patterns of Students from A Philippine University Fast-food Mall", International Journal of Food Sciences and Nutrition, 52(6):515-520.

Baek, S. H., Ham, S. and Yang Il-Sun, (2006). "A Cross-Cultural Comparison of Fast Food Restaurant Selection Criteria Between Korean and Filipino College Students", International Journal of Hospitality Management, 25(4):683-698.

Canoğlu, M. ve Ballı, E. (2017). “Tüketicilerin Kebap Restoranı Tercihlerini Etkileyen Faktörler Adana Örneği", Organizasyon ve Yönetim Bilimleri Dergisi, 10(1):30-43.

Clark, M. A. and Wood, R. C. (1998). "Consumer Loyalty in The Restaurant Industry - A Preliminary Exploration of the Issues", International Journal of Contemporary Hospitality Management, 10(4):139-144.

Goyal, A. and Singh, N. P. (2007). "Consumer Perception About Fast Food in India: An Exploratory Study", British Food Journal, 109(2):182-195. 
Hsu, C. H.C., Byun, S. and Yang, Il-Sun. (1997). "Attitudes of Korean College Students Towards Quick-Service, Family-Style, And Fine Dining Restaurants", Journal of Restaurant and Foodservice Marketing, 2(4):65-85.

June, L. P. and Smith, S. L. J. (1987). "Service Attributes and Situational Effects On Customer Preferences for Restaurant Dining", Journal of Travel Research, Fall, pp.20-27.

Kara, A., Kaynak, E. ve Kucukemiroglu, O. (1996). "Positioning of Fast -Food Outlets in Two Regions of North America: A Comparative Study Using Correspondence Analysis", Journal of Professional Services Marketing, 14(2):99-119.

Karakaş, A., Bilgin, Y. ve Kıngır, S. (2017). “Restoran İşletmelerinde Müşteri Memnuniyetinin Müşteri Sadakatine Etkisi: Amasra'da Faaliyet Gösteren Balık Restoranları Üzerine Bir Araştırma", 4th International Congress of Tourism \& Management Researches, 12-14 May 2017 Erişim: https://www.researchgate.net/publication/318570622_Restoran_Isletmelerinde_Musteri_Memnu niyetinin_Musteri_Sadakatine_Etkisi_Amasra\%27da_Faaliyet_Gosteren_Balik_Restoranlari_Uz erine_Bir_Arastirma_The_Impact_of_Customer_Satisfaction_on_Customer_Loyalty_in

Karakaş, Y. E., Çiçek, B. İ. ve Aysen, E. (2015). "Yerel ve Uluslararası Markalı Yiyecek İçecek İşletmelerinin Tercih Edilme Nedenlerini Belirlemeye Yönelik Bir Araştırma", 16. Ulusal Turizm Kongresi Bildiriler Kitabı, Çanakkale, ss. 1268-1284.

Kivela, J. J. (1997). "Restaurant Marketing: Selection and Segmentation in Hong Kong", International Journal of Contemporary Hospitality Management, 9(3):116-123.

Knutson, B. J. (2000). “College Students and Fast-Food: How Students Perceive Restaurant Brands", Cornell Hotel and Restaurant Administration Quarterly, 41(3):68-74.

Kotler, P., Armstrong, G., Saunders, J. and Wong, V. (1996). Principles of Marketing. First European Edition, New Jersey: Prentice Hall.

Lewis, R. C. (1981). "Restaurant Advertising: Appeals and Consumers' Intentions", Journal of Advertising Research, 21(5):69-74.

Laroche, M., Takahashi, I., Kalamas, M. and Teng, L. (2005). “Modeling The Selection of FastFood Franchises Among Japanese Consumers", Journal of Business Research, 58(8):1121-1131.

Mamalis, S. (2009). "Critical Success Factors of The Food Service Industry", Journal of International Food and Agribusiness Marketing, 21(2-3):191-206.

Miller, K. E. and Ginter, J. L. (1979). “An Investigation of Situational Variation in Brand Choice Behavior and Attitude", American Marketing Association, 16(1):111-123.

Özdemir, B. (2010). "Dışarıda Yemek Yeme Olgusu: Kuramsal Bir Model Önerisi", Anatolia: Turizm Araştırmaları Dergisi, 21(2):218-232.

Park, C. (2004). "Efficient or Enjoyable? Consumer Values of Eating-Out and Fast-Food Restaurant Consumption in Korea", International Journal of Hospitality Management, 23(1):87-94.

Rumore, N., Zhiwei, Z., Tanner, J. and Scheuermann, L. (1999). “Effectiveness of Competitive Strategies in Fast-Food Markets: An Analysis of Customers' Preferences", Journal of Restaurant and Foodservice Marketing, 3(3/4):39-47.

Sweeney, J. C., Johnson, L. W. and Armstrong, R. W. (1992). “The Effect of Cues On Service Quality Expectations and Service Selection in A Restaurant Setting", The Journal of Services Marketing, 6(4):15-22. 
Tayfun, A. ve Kara, D. (2007). “Turizm İşletme Belgeli Restoranlardan Hizmet Alan Müşterilerin Memnuniyet Düzeyleri Üzerine Bir Araştırma" Elektronik Sosyal Bilimler Dergisi, 6(21): 273-292

Tayfun, A. ve Tokmak, C. (2007). “Tüketicilerin Türk Usulü Fast Food İşletmelerini Tercih Etme Sebepleri Üzerine Bir Araştırma", Elektronik Sosyal Bilimler Dergisi 6(26):169-183.

Tichaawa, T. M. and Mhlanga, O. (2016). "What Are the Current Factors Affecting Consumer Selection Criteria in Formal Full Service Restaurants in Port Elizabeth, South Africa?" African Journal of Hospitality, Tourism and Leisure, 5(2):1-11.

Yamane, T. (2001). Temel Örnekleme Yöntemleri. (İngilizceden Çeviren: Alptekin, E., Bakır, C. Aydın, C. ve Gürbüzsel, E. İstanbul: Literatür Yayıncılık.

Yüksel, A. and Yüksel, F. (2003). "Measurement of Tourist Satisfaction with Restaurant Services: A Segment-Based Approach", Journal of Vacation Marketing, 9(1): 52-68.

Yüksekbilgili, Z. (2014). "Restoran Seçim Ölçütleri Üzerine Bir Araştırma", Journal of Yaşar University, 9(36): 6353-6360.

Zopiatis, A. and Pribic, J. (2007). “College Students' Dining Expectations in Cyprus”, British Food Journal, 109(10):765-776.

\section{EKLER:}

Demografik Değişkenlere Göre Kriter Sıralama Tablosu

\begin{tabular}{|c|c|c|c|c|c|c|c|c|c|c|c|c|c|c|c|c|c|c|c|c|}
\hline \multirow[b]{2}{*}{$\underset{\omega}{\leftrightarrows}$} & \multirow{2}{*}{ 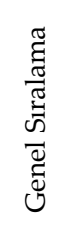 } & \multicolumn{6}{|c|}{ Aylık Gelir } & \multicolumn{6}{|c|}{ Dışarıda Yeme Sıklığ 1} & \multicolumn{6}{|c|}{ Meslek } & \multirow{2}{*}{ 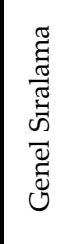 } \\
\hline & & $\begin{array}{l}\frac{E}{4} \\
\text { g } \\
\text { ब }\end{array}$ & $\begin{array}{l}\text { হ } \\
\text { ๙ } \\
1 \\
8 \\
8 \\
8\end{array}$ & $\begin{array}{l}\text { হ } \\
\text { ஜ) } \\
1 \\
8 \\
8 \\
8 \\
8\end{array}$ & $\begin{array}{l}\text { হ } \\
\text { হ } \\
1 \\
8 \\
8 \\
8\end{array}$ & $\begin{array}{l}\text { হ } \\
\text { হ } \\
1 \\
8 \\
8 \\
\varnothing\end{array}$ & $\begin{array}{l}+ \\
8 \\
8 \\
8\end{array}$ & 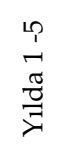 & 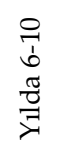 & $\begin{array}{l}\vec{\pi} \\
\frac{\pi}{2}\end{array}$ & $\begin{array}{l}10 \\
1 \\
2 \\
\frac{\pi}{0} \\
0 \\
\frac{2}{4}\end{array}$ & $\begin{array}{l}a \\
1 \\
0 \\
0 \\
0 \\
0 \\
\dot{2}\end{array}$ & 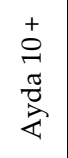 & 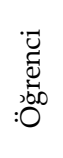 & $\begin{array}{l}\frac{\widetilde{\sigma}}{\pi} \\
\underset{\nabla}{\Sigma} \\
\underset{\Sigma}{\pi}\end{array}$ & 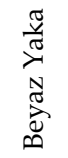 & 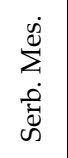 & $\underset{\Xi}{\Xi}$ & $\frac{i=7}{\stackrel{v}{\Xi}}$ & \\
\hline 1 & K46 & K46 & K46 & K46 & K9 & K31 & K46 & K41 & K9 & K25 & K46 & K46 & K46 & K46 & K46 & K46 & K41 & K46 & K43 & K46 \\
\hline 2 & K41 & K9 & K41 & K41 & K41 & K41 & K9 & K9 & K25 & K46 & K41 & K9 & K9 & K5 & K5 & K9 & K46 & K9 & K41 & K41 \\
\hline 3 & K9 & K48 & K43 & K9 & K46 & K45 & K31 & K45 & K41 & K41 & K45 & K41 & K45 & K16 & K16 & K31 & K48 & K25 & K25 & K9 \\
\hline 4 & K45 & K41 & K45 & K48 & K45 & K46 & K45 & K46 & K46 & K43 & K25 & K31 & K41 & K41 & K41 & K45 & K45 & K45 & K45 & K45 \\
\hline 5 & K48 & K43 & K25 & K45 & K10 & K9 & K48 & K48 & K43 & K45 & K31 & K48 & K31 & K4 & K4 & K41 & K9 & K41 & K9 & K48 \\
\hline 6 & K31 & K45 & K31 & K25 & K25 & K28 & K25 & K25 & K10 & K48 & K9 & K45 & K48 & K25 & K25 & K48 & K31 & K31 & K46 & K31 \\
\hline 7 & K25 & K25 & $\mathrm{K} 9$ & K31 & K31 & K10 & K5 & K43 & K37 & K9 & K48 & K43 & K43 & K34 & K34 & K25 & K25 & K48 & K48 & K25 \\
\hline 8 & K43 & K31 & K48 & K43 & K43 & K25 & K10 & K10 & K48 & K31 & K43 & K25 & K10 & K43 & K43 & K37 & K43 & K43 & K31 & K43 \\
\hline 9 & K10 & K39 & K37 & K37 & K48 & K37 & K17 & K34 & K31 & K36 & K39 & K37 & K25 & K9 & K9 & K39 & K37 & K10 & K39 & K10 \\
\hline 10 & K37 & K10 & K10 & K10 & K37 & K39 & K28 & K30 & K45 & K10 & K37 & K10 & K4 & K10 & K10 & K43 & K10 & K36 & K10 & K37 \\
\hline 11 & K39 & K34 & K39 & K36 & K36 & K48 & K37 & K39 & K36 & K37 & K36 & K5 & K17 & K28 & K28 & K10 & K39 & K37 & K30 & K39 \\
\hline 12 & K36 & K36 & K36 & K39 & K28 & K3 & K41 & K42 & K4 & K30 & K10 & K4 & K37 & K30 & K30 & K30 & K17 & K34 & K36 & K36 \\
\hline 13 & K34 & $\mathrm{K} 4$ & K34 & K28 & K4 & K36 & K4 & K47 & K42 & K39 & K34 & K36 & K39 & K31 & K31 & K4 & K36 & K39 & K37 & K34 \\
\hline 14 & K17 & K37 & K30 & K47 & K39 & K17 & K39 & K17 & K47 & K42 & K47 & K39 & K34 & K42 & K42 & K17 & K28 & K28 & K42 & K17 \\
\hline 15 & K4 & K47 & K17 & K17 & K34 & K4 & K36 & K31 & K39 & K28 & K17 & K34 & K36 & K17 & K17 & K34 & K4 & K47 & K17 & K4 \\
\hline 16 & K47 & K17 & K42 & K34 & K3 & K29 & K47 & K16 & K17 & K34 & K28 & K47 & K42 & K36 & K36 & K5 & K47 & K17 & K28 & K47 \\
\hline 17 & K30 & K30 & $\mathrm{K} 4$ & K30 & K47 & K30 & K11 & K28 & K29 & K17 & K30 & K28 & K5 & K37 & K37 & K42 & K3 & K4 & K29 & K30 \\
\hline 18 & K42 & K42 & K5 & K42 & K17 & K47 & K43 & K29 & K16 & K5 & K4 & K42 & K47 & K45 & K45 & K3 & K16 & K42 & K3 & K42 \\
\hline 19 & K5 & K5 & K16 & K5 & K30 & K13 & K3 & K36 & K28 & K47 & K42 & K16 & K30 & K48 & K48 & K36 & K34 & K30 & K40 & K5 \\
\hline 20 & K28 & K16 & K28 & K16 & K13 & K22 & K13 & K37 & K30 & K22 & K22 & K30 & $\mathrm{K} 3$ & K39 & K39 & K47 & $\mathrm{K} 5$ & K5 & K47 & K28 \\
\hline 21 & K16 & K29 & K47 & K4 & K42 & K34 & K42 & K5 & K5 & K29 & K3 & K17 & K16 & K40 & K40 & K28 & K42 & K16 & K5 & K16 \\
\hline 22 & K3 & K7 & K40 & K22 & K22 & K43 & K16 & K1 & K8 & K11 & K5 & K3 & K7 & K3 & K3 & K16 & K40 & K22 & K16 & K3 \\
\hline 23 & K40 & K13 & K3 & K3 & K29 & K40 & K29 & K19 & K11 & K7 & K16 & K40 & K28 & K7 & K7 & K22 & K29 & K24 & K4 & K40 \\
\hline 24 & K29 & K24 & K7 & K11 & K24 & K8 & K26 & K4 & K34 & K16 & K13 & K13 & K40 & K22 & K22 & K7 & K11 & K29 & K22 & K29 \\
\hline 25 & K22 & K40 & K29 & K24 & K32 & K42 & K34 & K6 & K32 & K4 & K29 & K7 & K24 & K47 & K47 & K13 & K30 & K13 & K34 & K22 \\
\hline
\end{tabular}




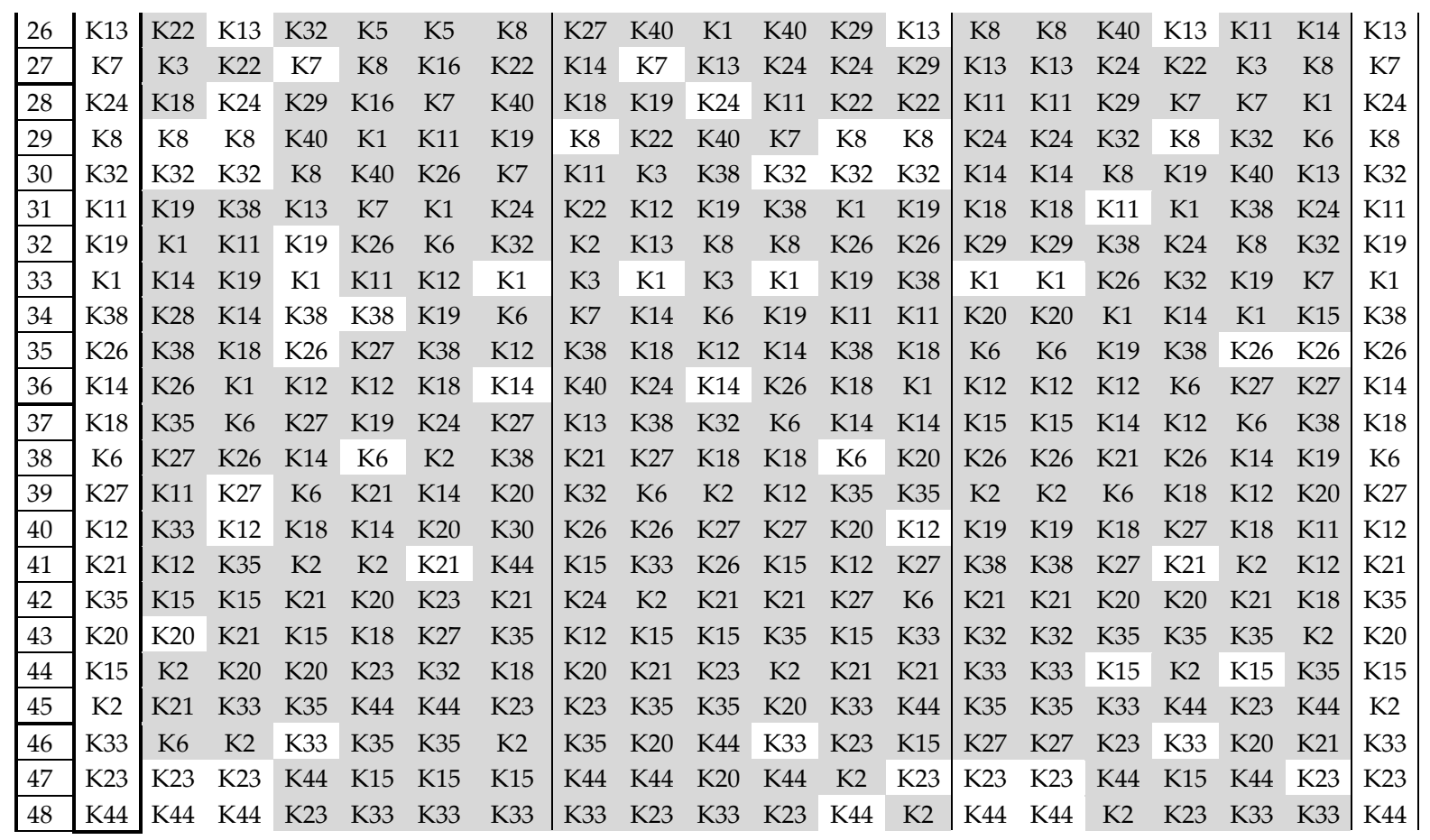

Demografik Değişkenlere Göre Kriter Sıralama Tablosu

\begin{tabular}{|c|c|c|c|c|c|c|c|c|c|c|c|c|c|c|c|c|c|c|c|}
\hline \multirow{2}{*}{ હ } & \multirow{2}{*}{ 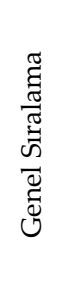 } & \multicolumn{6}{|c|}{ Yaş } & \multicolumn{2}{|c|}{ Cinsiyet } & \multicolumn{5}{|c|}{ Öğrenim Düzeyi } & \multicolumn{2}{|c|}{$\begin{array}{l}\text { Medeni } \\
\text { Durum }\end{array}$} & \multicolumn{2}{|c|}{$\begin{array}{c}\text { Çocuk } \\
\text { Durumu }\end{array}$} & \multirow{2}{*}{ 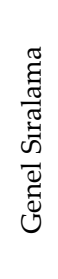 } \\
\hline & & 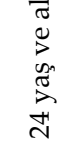 & 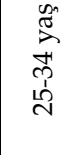 & 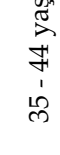 & 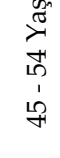 & \begin{tabular}{l} 
त्र \\
\multirow{H}{*}{} \\
1 \\
Ln
\end{tabular} & 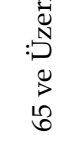 & 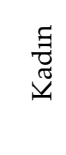 & 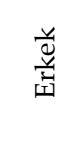 & 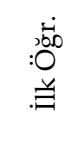 & $\stackrel{\mathscr{n}}{.}$ & 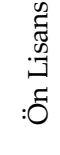 & 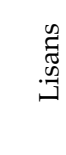 & 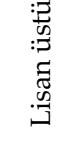 & 景 & 苂 & $\begin{array}{l}\tilde{z} \\
\vec{z} \\
\ddot{z} \\
\dot{0}\end{array}$ & 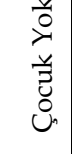 & \\
\hline 1 & K46 & K46 & K46 & K46 & K41 & K43 & K9 & K46 & K46 & K41 & K41 & K41 & K46 & K46 & K46 & K46 & K46 & K46 & K46 \\
\hline 2 & 41 & K45 & K31 & K9 & K46 & K25 & K25 & K41 & K9 & K43 & K46 & K46 & K45 & K9 & K41 & K9 & K41 & K9 & K41 \\
\hline 3 & K9 & K48 & K9 & K41 & K45 & K9 & K39 & K48 & K45 & K31 & K43 & K48 & K9 & K31 & K45 & K41 & K45 & K31 & K9 \\
\hline 4 & K45 & K9 & K41 & K45 & K25 & K31 & K41 & K9 & K41 & K48 & K9 & K25 & K41 & K45 & K9 & K31 & K25 & K41 & K45 \\
\hline 5 & K48 & K43 & K25 & K 48 & K48 & K41 & K43 & K45 & K31 & K1 & K25 & K45 & K31 & K48 & K25 & K48 & K48 & K45 & K48 \\
\hline 6 & K31 & K31 & K48 & K25 & K9 & K28 & K22 & K25 & K43 & K9 & K48 & K9 & K48 & K41 & K48 & K45 & K9 & K48 & K31 \\
\hline 7 & K25 & K41 & K45 & K31 & K10 & K30 & K28 & K31 & K25 & K10 & K45 & K31 & K25 & K25 & K31 & K43 & K43 & K43 & K25 \\
\hline 8 & K43 & K39 & K43 & K43 & K43 & K45 & K31 & K37 & K48 & K17 & K10 & K43 & K43 & K37 & K43 & K25 & K31 & K25 & K43 \\
\hline 9 & K10 & K34 & K34 & K10 & K31 & K46 & K36 & K43 & K10 & K42 & K37 & K36 & K10 & K43 & K10 & K4 & K10 & K39 & K10 \\
\hline 10 & K37 & K25 & K37 & K37 & K36 & K37 & K46 & K36 & K39 & K46 & K39 & K10 & K39 & K34 & K37 & K39 & K37 & K4 & K37 \\
\hline 11 & K39 & K4 & K4 & K39 & K37 & K48 & K48 & K10 & K34 & K25 & K31 & K37 & K37 & K36 & K36 & K10 & K36 & K10 & K39 \\
\hline 12 & K36 & K10 & K39 & K36 & K17 & K39 & K1 & K39 & K37 & K39 & K36 & K17 & K36 & K10 & K39 & K37 & K39 & K37 & K36 \\
\hline 13 & K34 & K5 & K17 & K47 & K28 & K3 & K6 & K17 & K28 & K40 & K47 & K30 & K4 & K4 & K28 & K34 & K28 & K34 & K34 \\
\hline 14 & K17 & K30 & K10 & K28 & K47 & K10 & K10 & K47 & K4 & K6 & K17 & K39 & K34 & K5 & K34 & K36 & K34 & K5 & K17 \\
\hline 15 & K4 & K47 & K36 & K17 & K39 & K16 & K14 & K30 & K36 & K11 & K34 & K42 & K30 & K39 & K47 & K17 & K17 & K36 & K4 \\
\hline 16 & K47 & K42 & K42 & K34 & K34 & K42 & K17 & K34 & K5 & K37 & K40 & K34 & K17 & K47 & K17 & K5 & K47 & K17 & K47 \\
\hline 17 & K30 & K36 & K5 & K11 & K30 & K5 & K24 & K42 & K16 & K45 & K28 & K28 & K5 & K16 & K30 & K42 & K30 & K42 & K30 \\
\hline 18 & K42 & K16 & K30 & K4 & K4 & K17 & K29 & K4 & K47 & K2 & K16 & K47 & K42 & K17 & K42 & K30 & K42 & K47 & K42 \\
\hline 19 & K5 & K17 & K16 & K5 & K29 & K36 & K30 & K5 & K30 & K14 & K5 & K4 & K47 & K3 & K5 & K47 & K11 & K30 & K5 \\
\hline 20 & K28 & K37 & K28 & K42 & K42 & K40 & K34 & K29 & K17 & K16 & K42 & K3 & K28 & K28 & K4 & K7 & K4 & K16 & K28 \\
\hline 21 & K16 & K7 & K47 & K30 & K3 & K22 & K35 & K13 & K42 & K22 & K30 & K16 & K16 & K22 & K16 & K3 & K16 & K7 & K16 \\
\hline 22 & K3 & K13 & K7 & K16 & K5 & K4 & K37 & K28 & K3 & K24 & K29 & K29 & K3 & K42 & K11 & K16 & K5 & K3 & K3 \\
\hline 23 & K40 & K3 & K3 & K22 & K22 & K29 & K38 & K40 & K24 & K3 & K4 & K5 & K40 & K30 & K22 & K40 & K22 & K40 & K40 \\
\hline 24 & K29 & K24 & K24 & K3 & K16 & K34 & K45 & K7 & K22 & K4 & K22 & K7 & K7 & K7 & K3 & K13 & K3 & K13 & K29 \\
\hline 25 & K22 & K40 & K13 & K29 & K40 & K47 & K4 & K16 & K40 & K7 & K3 & K24 & K13 & K13 & K29 & K29 & K29 & K24 & K22 \\
\hline
\end{tabular}




\begin{tabular}{|c|c|c|c|c|c|c|c|c|c|c|c|c|c|c|c|c|c|c|c|}
\hline 20 & 13 & 18 & 40 & & K13 & K1 & K8 & & & K19 & & K40 & K22 & K29 & 24 & К24 & K40 & $<29$ & \\
\hline & 7 & K29 & K29 & & K8 & & & & & & & & & & & & & $<22$ & \\
\hline & 24 & 8 & K22 & & $\mathrm{K} 7$ & & & & & & & & & & & & & 28 & 24 \\
\hline & & & & & K1 & & & & & & & & & & & & K24 & K8 & 8 \\
\hline & 2 & & & & K32 & & & & & & & K1 & & & K8 & & & K32 & 32 \\
\hline & & & $\mathrm{K} 8$ & & & & & & & & & & & & & & & & \\
\hline & & 38 & K14 & & 38 & & & & & & & & & & & & & 38 & K19 \\
\hline & & K1 & $\mathrm{K} 1$ & & 26 & & & & & & & & & & & & & 18 & 61 \\
\hline & & & & & & & & & & & & & & & & & & 26 & 38 \\
\hline & 26 & 28 & $\mathrm{~K}$ & & 14 & 26 & & & & & & $\mathrm{~K}$ & & & & & & K1 & 26 \\
\hline & 14 & & & K26 & K18 & & & & & & & & & 6 & 26 & & & 14 & K14 \\
\hline & & & $\mathrm{K} 2$ & & 12 & & & & & & & & & & 6 & & & 27 & K18 \\
\hline & & K15 & K6 & K18 & K19 & & & & & & & & K27 & & 14 & 2 & & 35 & K6 \\
\hline & & & & & K27 & & & & & & & & & & & & & 20 & $<27$ \\
\hline & & & & & KG & & & & & & & & & & 21 & $K^{\prime}$ & & & K12 \\
\hline & & & & & V? & & & & & & & & & & 18 & & & 33 & 21 \\
\hline & & & & & & & & & & & & & & & K2 & & & 15 & 35 \\
\hline & & & & & & & & & & & & & & & & & & K23 & К20 \\
\hline 44 & 15 & K12 & K33 & & & & & & & & & & & & & K12 & & K2 & K15 \\
\hline 45 & & K2 & $\mathrm{K} 2$ & & K35 & & & & & & & & & & 35 & & & 44 & K2 \\
\hline 46 & & & & & & & & & & & & & & & & & & 12 & 33 \\
\hline 47 & & & & & 23 & & & & & & & & & & 33 & 44 & & 21 & K23 \\
\hline & & & K23 & & & & & & & & & & & & K44 & & & K11 & \\
\hline
\end{tabular}

